Provided by the author(s) and University of Galway in accordance with publisher policies. Please cite the published version when available.

\begin{tabular}{|c|l|}
\hline Title & $\begin{array}{l}\text { Pile groups under axial loading: an appraisal of simplified non- } \\
\text { linear prediction models }\end{array}$ \\
\hline Author(s) & $\begin{array}{l}\text { Lehane, B.M.; Sheil, Brian B.; McCabe, Bryan A.; } \\
\text { Comodromos, Emilios M.; Lehane, Barry M. }\end{array}$ \\
\hline $\begin{array}{c}\text { Publication } \\
\text { Date }\end{array}$ & 2019-06-12 \\
\hline $\begin{array}{c}\text { Publication } \\
\text { Information }\end{array}$ & $\begin{array}{l}\text { Sheil, Brian B., McCabe, Bryan A., Comodromos, Emilios M., } \\
\text { appraisal of simplified non-linear prediction models. } \\
\text { Géotechnique, 69(7), 565-579. doi: 10.1680/jgeot.17.R.040 }\end{array}$ \\
\hline $\begin{array}{c}\text { Publisher } \\
\text { Thomas Telford (ICE Publishing) }\end{array}$ \\
\hline $\begin{array}{c}\text { Link to } \\
\text { publisher's } \\
\text { version }\end{array}$ & https://doi.org/10.1680/jgeot.17.R.040 \\
\hline $\begin{array}{c}\text { Item record } \\
\text { http://hdl.handle.net/10379/15226 }\end{array}$ \\
\hline
\end{tabular}

Downloaded 2023-04-26T09:58:32Z

Some rights reserved. For more information, please see the item record link above. 
Cite as: Sheil, B.B., McCabe, B.A., Comodromos, E.M., Lehane' B.M. (2019) Pile groups under axial loading: an appraisal of simplified nonlinear prediction models, Geotechnique, Vol. 69, No. 7, pp. 565-579.

\section{Pile groups under axial loading: an appraisal of simplified nonlinear prediction models}

Brian B. Sheil ${ }^{1 *}$, Bryan A. McCabe ${ }^{2}$, Emilios M. Comodromos ${ }^{3}$, Barry M. Lehane ${ }^{4}$

${ }^{1}$ Departmental Lecturer, Department of Engineering Science, University of Oxford, U.K.

${ }^{2}$ Senior Lecturer, Civil Engineering, College of Engineering and Informatics, National University of Ireland, Galway, Ireland

${ }^{3}$ Professor, Department of Civil Engineering, University of Thessaly, Greece.

${ }^{4}$ Professor, School of Civil, Environmental and Mining Engineering, The University of Western Australia, Crawley, Australia

*Corresponding author. Email: brian.sheil@eng.ox.ac.uk. Tel.: +44 (0)1865 283148 


\begin{abstract}
The settlement behaviour of vertically-loaded pile groups has been the subject of an extensive body of research over the past two decades. In particular, this work has identified the overconservatism associated with predictions of pile interaction derived from elastic theory and the corresponding amplification of group settlement relative to single pile values. Researchers have since redoubled efforts to refine settlement predictions for pile groups towards more economical design, largely through more rigorous treatment of soil stiffness nonlinearity. Although foundation design engineers are increasingly employing three-dimensional continuum analyses to quantify pile interaction on a site-specific basis, simplified design approaches remain an integral part of preliminary foundation design. The purpose of this paper is to undertake a critical examination of these methods with a view to increasing their potential for take-up by foundation engineering practitioners. A database of simplified models has been collated for the prediction of nonlinear pile interaction that exists within vertically-loaded pile groups. These models are categorised as either analytical or empirical. The development, limitations, and range of applicability of these models are explored in detail in the context of some published case histories.
\end{abstract}




\section{INTRODUCTION}

Pile foundations have been used for centuries as a means of transmitting structural loads to competent strata at depth in the ground. Piles installed in groups have the potential to carry large loads and are often the only viable solution when structures to be supported are heavy, or when the ground conditions are challenging. Traditionally, the emphasis in pile design was on predicting ultimate pile capacity, with a large factor of safety ensuring that settlements were small, formal estimates of which could often be avoided. More recently, this focus has shifted towards more economical serviceability limit-state design thereby prompting considerable research effort to refine predictions of single pile and pile group settlement. In particular, this has necessitated more reliable modelling of the development of pile-soil interface resistance during loading as well as more realistic treatment of pile-to-pile interaction.

An important outcome of research into the settlement behaviour of pile groups under axial loads is that predictions based on elastic theory alone are excessively conservative. As a result, the application of nonlinear frameworks to pile groups has increased substantially over the last two decades. Within a nonlinear framework, pile settlement is no longer uncoupled from the ultimate capacity and therefore an accurate estimation of capacity is a prerequisite for a rigorous analysis of the serviceability limit state. While three-dimensional nonlinear continuum analyses are becoming more commonplace, simplified design approaches remain an integral part of preliminary foundation design. There is now a myriad of approaches in the literature for the prediction of nonlinear pile interaction. The purpose of this paper is to undertake a critical examination of a selection of these methods, in the context of selected case histories, with a view to increasing their potential for take-up by foundation engineering practitioners; the primary focus is on developments since the seminal review paper on pile groups by Poulos (2006).

The settlement behaviour of piled foundations subjected to vertical loads is potentially governed by both pile-to-pile interaction and pile-soil-raft interaction (Ghalesari et al. 2015). Pile interaction effects, in particular those that exist between pile shafts, necessitate rigorous treatment as settlements are amplified relative to single pile values. Interaction between pile shafts is therefore central to this review. The role of soil stiffness nonlinearity on pile interaction is first considered. A database of existing simplified nonlinear models is collated, and categorised as either empirical or analytical. The associated assumptions, limitations, and applicability of each model are also discussed. Clearly the accuracy of any predictive model is dependent on the appropriateness of the input parameters. In light of this, careful consideration 
of the pile type, installation effects, and the corresponding soil responses (dilation, pore pressure generation and evolution of stresses for example) is paramount.

\section{BACKGROUND: PILE GROUP INTERACTIONS}

\section{Pile-soil-raft interaction}

According to Comodromos et al. (2016), the resistance of a piled raft can be partitioned into three stages depending on the group settlement normalized by the pile diameter, $S_{\mathrm{ng}}$ :

1. $0 \%<S_{\text {ng }}<1.5 \%$ : the resistance of both the piles and the raft are linear and the resistance contribution from the raft is insignificant and therefore commonly ignored (Mandolini and Viggiani 1997; Xu and Zhang 2007; Kumar et al. 2017);

2. $1.5 \%<S_{\mathrm{ng}}<4 \%$ : the piles exhibit up to $\sim 90 \%$ of their limit capacity;

3. $S_{\mathrm{ng}}>4 \%$ : additional resistance of the piled raft is essentially attributed to the raft.

Those authors reported that the maximum contribution from the raft (acting within the piled raft system) was considerably lower than the corresponding resistance of an isolated raft. It was also noted that the maximum resistance provided by the piles was essentially unaffected by the existence of the raft (Comodromos et al. 2009). In light of this, the spring elements replacing the soil resistance around the piles may be considered independent from those simulating the resistance under the raft.

\section{Nonlinear two-pile interaction factors}

The interaction factor method (IFM) is the most common means of accounting for pile interaction in the design of pile groups. This process essentially applies an amplification factor to the settlement of a single pile with the same applied load at the pile head. Initially, the interaction between a pair of piles ( $\mathrm{i}$ and $\mathrm{j}$ ) is quantified as a 'two-pile interaction factor', $\alpha$ :

$$
\alpha=\frac{\text { Additional settlement of pile } j \text { due to nearby loaded pile } i}{\text { Settlement of single pile under its own (equivalent) load }}
$$

Values of $\alpha$ may be computed for each pile spacing, $s$, occurring within the group. The principle of superposition is then applied to calculate the cumulative interaction occurring within the group. However, inconsistencies in how $\alpha$ is calculated feature in the literature. The receiver pile may be load-free (henceforth referred to as 'Approach I'; see Fig. 1(a)) or loaded (henceforth referred to as 'Approach II', see Fig. 1(b)). When used within a linear elastic (LE) 
framework, both approaches yield the same result. For real soils, however, the increased level of shear strain in the vicinity of a loaded pile causes a corresponding reduction in the soil modulus. The consideration of soil nonlinearity therefore results in different values of $\alpha$ depending on the applied load level and whether Approach I or Approach II is adopted (McCabe and Sheil 2015).

\section{Validity of superimposing nonlinear interaction factors - numerical investigations}

The principle of superposition is not valid in nonlinear engineering problems. Nevertheless, a number of studies have investigated the role of soil stiffness nonlinearity in pile interaction and pile group settlement. Caputo and Viggiani (1984) described a case history on the interaction between an identical pile pair. The pile load tests consisted of one loaded pile while the other nearby pile remained load-free (i.e. Approach I). These authors noted that while the response of the loaded pile was highly nonlinear, the settlement of the load-free pile increased linearly with increasing applied load on the loaded pile (see Fig. 2).

Using three-dimensional finite element analysis (FEA), Trochanis et al. (1991) noted that the axial response of a single pile is identical whether the soil is modeled as elastic or elastoplastic when slip is accommodated at the pile-soil interface as shown in Fig. 3 (see Fig. 1(a) for definitions of pile/soil parameters). These authors concluded that soil nonlinearity must therefore be concentrated at the pile-soil interface from which it was deduced that the soil remains in a linear elastic state outside of this narrow region.

Leung et al. (2010) investigated the role of linear elasticity in pile group analysis by appraising LE and nonlinear methods for the analysis of pile groups against hypothetical scenarios and published case histories. These authors observed that within a pile group the "nonlinearity in individual pile behavior becomes overwhelmed by the interaction effects" and therefore pile interaction is governed by elastic behaviour (see Fig. 4).

$\mathrm{Ju}$ (2015) explored the role of soil stiffness nonlinearity on pile interaction using threedimensional FEA. Three types of analyses were carried out: (1) a LE analysis of the entire soil domain; (2) a composite LE-nonlinear analysis where the soil immediately surrounding the piles was considered nonlinear and the rest of the soil considered LE; (3) a nonlinear analysis of the entire soil domain. This author noted that the type-2 analysis provided significantly improved agreement to field measurements by comparison to the type-1, which would be expected. Surprisingly, the agreement between FEA predictions and the measured response 
was poorer for the type- 3 compared to the type- 2 analysis. It should be noted, however, that this comparison is highly dependent on the equivalent elastic stiffness adopted in the type-2 analysis. Nevertheless, these comparisons revealed that soil stiffness nonlinearity is confined to a radial distance of one pile diameter from the pile surface, slightly greater than that implied by Caputo and Viggiani (1984).

McCabe and Sheil (2015) employed a constitutive model featuring a stress-dependent nonlinear stiffness to explore the appropriateness of nonlinear IFM for predicting pile group settlement. This was achieved through comparison of settlement predictions determined from (i) a full 3D analysis of the entire group and (ii) superposition of $\alpha$ using both Approach I and Approach II IFM. For floating pile groups, good agreement was observed between the direct and Approach I IFM methods. Comparisons between the direct and Approach II IFM predictions were less satisfactory. An example comparison is provided in Fig. 5 for a rigidlycapped floating pile group with a pile spacing-to-diameter $(s / D)$ ratio of 3 and a load factor $(L F)$ of 0.4 on the capacity of a single pile. Locating a stiffer stratum at the base of the piles was also shown to reduce the accuracy of Approach I predictions, although with a bias on the conservative side.

Wang et al. (2016a) presented similar comparisons between IFM and direct FEA. The IFM predictions involved coupling analytical single pile settlement predictions with the elastic interaction factors reported in Poulos and Davis (1980). Predictions of the total interaction experienced by a centre group pile for groups sizes, $N$, of 9,25 , and 49 piles are shown in Fig. 6. These authors suggested that "group reinforcing effects" on the soil continuum have a nonnegligible influence on the accuracy of IFM, when compared to FEA, and they proposed a 'linear approximate method' to account for group reinforcing effects that demonstrated improved agreement to the direct analyses. Wang et al. (2016b) presented additional numerical results in an effort to reconcile the differences between IFM and FEA. This process involved determining the value of $\alpha$ between a loaded source pile and a non-loaded receiver pile (labelled piles $a-d$ ) using Approach I within groups of increasing size (see Fig. 7). Figure 8 shows that the influence of group reinforcing effects (i.e. the presence of intervening nonloaded group piles) on $\alpha$ appear to be minimal for the group sizes and soil parameters considered in this example. 


\section{EMPIRICAL METHODS}

\section{Overview of existing methods}

Empirical approaches allow pile group settlement performance to be determined directly, but based on experience from field/laboratory tests or advanced numerical modelling rather than a theoretical basis. The pile group settlement ratio, $R_{\mathrm{s}}$, is the most common means of quantifying the extent of pile interaction within a pile group. This factor can be considered as an amplification factor on the settlement of a single pile subjected to an equivalent pile head load:

$$
R_{s}=\frac{w_{\text {group }}}{w_{\text {single }}}
$$

where $w_{\text {group }}$ and $w_{\text {single }}$ are the settlements of a pile group and single pile with the same head load per pile, respectively.

Skempton (1953) developed what appears to be the earliest empirical expression for $R_{\mathrm{S}}$ based on field tests of driven pile groups in sand:

$$
R_{s}=\left(\frac{4 B^{\prime}+2.7}{B^{\prime}+3.6}\right)^{2}
$$

where $B^{\prime}$ is the width of the plan area of the pile group in metres.

Meyerhof (1959) included the influence of pile spacing and the number of piles for square pile groups located in sand based on theoretical observations:

$$
R_{s}=\frac{s / D\left(5-\frac{(s / D)}{3}\right)}{\left(1+\frac{1}{n_{r}}\right)^{2}}
$$

where $n_{\mathrm{r}}$ is the number of rows of piles in a square pile group.

Vesic (1969) simply related $R_{\mathrm{s}}$ to the pile group width, $B_{\mathrm{g}}$, normalised by the pile diameter:

$$
R_{s}=\sqrt{\frac{B_{g}}{D}}
$$

Kaniraj (1993) developed a semi-empirical equation for $R_{\mathrm{s}}$. A new term was introduced by this author, termed the 'settlement ratio for equal stress', $R_{\mathrm{s}}$, and defined as the ratio of the settlement of a pile group to that of a single pile when the average stress on their respective load transmitting areas are equal: 


$$
R_{S}^{\prime}=1.128 \sqrt{\frac{\left(n_{r}-1\right)\left(n_{c}-1\right)(S / D)^{2}}{\left(1+2 \frac{L}{D} \tan \theta\right)^{2}}+\frac{\left(n_{r}+n_{c}-2\right)\left(\frac{S}{D}\right)}{1+2 \frac{L}{D} \tan \theta}+1}
$$

where $\theta$ is the load dispersion angle, taken as $\sim 7^{\circ}$ according to (Berezantzev et al. 1961), and $n_{\mathrm{c}}$ is the number of columns of piles in the pile group. The value of $R_{\mathrm{S}}$ may then be determined as follows:

$$
R_{s}=1+0.67\left(\frac{N_{p}}{R_{S}^{\prime}} \frac{S_{s h}}{S_{s h}^{\prime}}-1\right)
$$

where $S_{\text {sh }}^{\prime}$ and $S_{\text {sh }}$ are the secant slopes of the hypothetical single pile load-displacement curve under loads of $q A_{\mathrm{g}} / N$ and $q A_{\mathrm{s}}$ respectively and $q$ is the applied stress. The term $S_{\text {sh }}^{\prime} / S_{\mathrm{sh}}$ is used to account for soil nonlinearity.

Castelli and Maugeri (2002) developed an approach based on the equivalent pier method combined with a hyperbolic load-transfer function to model nonlinear interaction with soil:

$$
R_{S}=\left(\frac{D}{D_{g}}\right)^{-\varepsilon}
$$

where $D_{g}$ is the equivalent diameter of the plan area of the pile group, and an exponent of $\varepsilon=$ 0.15 was derived from a limited database of pile group case histories.

McCabe and Lehane (2006) recast the Castelli and Maugeri (2002) approach to provide improved agreement to a database of nine published pile group case histories. However, these authors considered the group stiffness efficiency, $\eta_{\mathrm{g}}$, defined as the inverse of $R_{\mathrm{s}}$ :

$$
\eta_{\mathrm{g}}=R_{\mathrm{s}}^{-1}=\frac{\left[D_{g} / D\right]^{0.66}}{N}
$$

Comodromos (2004) developed an approach through curve-fitting to numerically-derived values of $R_{\mathrm{s}}$. Three-dimensional finite difference analyses using an elastic-plastic soil model were adopted for this purpose. The group sizes considered in the parametric analyses ranged from 4 piles to 25 piles while a spacing of three pile diameters was maintained. Comodromos and Bareka (2009) presented additional numerical analyses to extend the applicability of their earlier approach to pile spacings ranging between two and five pile diameters, a broader range of clayey soils, and alternative group configurations. Their expression is given below:

$$
R_{S}=0.8\left[S_{n s}^{0.07}\left(1.23 N_{R}\right)^{1.9}+S_{n s}^{-0.08} \mathrm{e}^{0.54 N_{R}}\right] \ln \left(1.25+\frac{5}{S / D}\right)
$$


where $S_{\mathrm{ns}}$ is the settlement of a single pile, normalised by the pile diameter and $N_{\mathrm{R}}$ is defined by Comodromos et al. (2016) for large group sizes:

$$
N_{R}=\frac{(N+5)^{0.85}}{n_{r}+n_{c}}
$$

Sheil and McCabe (2014) developed closed-form equations by curve-fitting results obtained from 3D FEA using a nonlinear soil model. The influence of pile spacing, length, group geometry and size, as well as the depth and stiffness of an underlying bearing stratum were all considered in the parametric analyses. Three sets of equations to predict $\eta_{\mathrm{g}}$ were developed for (i) pile groups in infinitely deep soil mass $(h / L \geq 3)$, (ii) pile groups in a finite soil mass $(1<$ $h / L<3$ ), and (iii) pile groups end-bearing on a stiff soil stratum $(h / L=1)$, where $h$ is the depth below ground level to a stiff bearing stratum.

For case (i), the following equation was developed where $\eta_{\mathrm{f}}$ signifies $\eta_{\mathrm{g}}$ for a floating pile group:

$$
\eta_{\mathrm{g}}=\eta_{\mathrm{f}}=\frac{\left[D_{g} / D\right]^{\mathrm{A}}}{N+1}
$$

where $A=0.83(L / D)^{-0.071}$. To account for the presence of a stiff bearing stratum beneath the base of the pile group (case (ii)), additional terms were added to equation (12):

$$
\eta_{\mathrm{g}}=\eta_{\mathrm{f}}+B\left(\frac{1}{h / L}\right)^{6}
$$

where $B=0.147(L / D)^{-0.272} \ln N$. Finally, the expression developed for case (iii) was defined as follows:

$$
\eta_{\mathrm{g}}=\eta_{\mathrm{f}} \times\left(\frac{E_{2}}{E_{1}}\right)^{C}
$$

where $E_{2} / E_{2}$ is the stiffness of the bearing stratum relative to the soil along the pile shaft, and $C=0.112 \ln N-0.11$.

\section{Comparison of empirical methods}

Predictions of $R_{\mathrm{s}}$ determined by these empirical approaches are compared in Fig. 9 for a variation in the number of piles (Fig. 9(a)) and pile spacing-to-length ratio ( $s / L$; Fig. 9(b)). A selection of comparable field data has also been superimposed on these figures; the relevant 
particulars are provided in Table 1. From Fig. 9(a), it can be seen that the associated predictions span a relatively broad spectrum. This highlights the importance of the data used in the development, calibration, and validation of these models and the corresponding range of applicability (see Table 2). In particular, the approaches developed by Comodromos (2004) and Comodromos and Bareka (2009) predict a steep increase in $R_{\mathrm{s}}$ with an increase in pile numbers. Comodromos et al. (2016) noted, however, that this approach was developed for smaller pile groups $(N \lesssim 25)$ and is likely to over-predict $R_{\mathrm{s}}$ for large groups. It can also be seen that predictions determined using the Skempton (1953) and Vesic (1969) are overly conservative, particularly for smaller pile groups. In contrast, predictions determined using the Castelli and Maugeri (2002) approach plot notably lower. This is due to the large proportion of end-bearing pile groups in the database of case histories used for calibration.

Considering the influence of $s / L$ in Fig. 9(b), the three oldest approaches in this comparison predict an increase in $R_{\mathrm{S}}$ with increasing $s / L$ predictions (the Meyerhof (1959) predictions exhibit a turning point at $s / L \approx 0.3$ ), which contradicts the more recent approaches as well as the field data. This is probably due to the limited data from which the latter methods were developed.

\section{ANALYTICAL METHODS}

\section{Overview of existing pile shaft interaction models}

The aforementioned research on nonlinear soil behaviour has formed a basis for the use of the principle of superposition in nonlinear simplified predictive methods. These approaches vary in the number of parameters required to calibrate soil nonlinearity, their treatment of the elastic interaction displacements and conditions at the pile-soil interface such as whether slip is allowed (see Table 2).

Caputo and Viggiani (1984) documented one of the earliest nonlinear pile interaction methods. These authors compiled all values of $\alpha$ that exist with a group into a single interaction matrix. Off-diagonal entries, $\alpha_{\mathrm{ij}}(i \neq j)$, were assumed constant (independent of load level), whereas $\alpha_{\mathrm{ii}}$ varied depending on the load level to account for soil nonlinearity:

$$
\alpha_{i i}=\frac{1}{1-\frac{Q_{i}}{Q_{i, l i m}}}
$$


where $\alpha_{\mathrm{ii}}$ is the interaction factor for pile $i$ under its own load, $Q_{\mathrm{i}}$, and the ultimate load is $Q_{\mathrm{i}, \mathrm{lim}}$, as defined in Chin (1970).

Lee (1993) documented a simplified hybrid layer approach for predicting pile interaction; a hyperbolic relationship between mobilised shear stress and displacement at the pile-soil interface was used to consider soil stiffness nonlinearity. This author modified the Randolph and Wroth (1978) elastic model, introducing a new stress-dependent $\beta$ term. The incremental soil settlement $\Delta w_{\mathrm{s}}$ for a single pile is obtained as follows:

$$
\begin{gathered}
\Delta w_{s}=\frac{\Delta \mathrm{P}_{s}}{2 \pi G_{t} L}\left[\ln \left(\frac{r_{m}-\beta}{r_{0}-\beta}\right)+\frac{\beta\left(r_{m}-r_{0}\right)}{\left(r_{m}-\beta\right)\left(r_{0}-\beta\right)}\right] \\
\beta=\tau_{0} r_{0} R_{f} / \tau_{f},
\end{gathered}
$$

where $\Delta P_{\mathrm{s}}$ is the incremental load at the shaft node, $G_{\mathrm{t}}$ is the initial tangent shear modulus at the pile shaft, $L$ is the pile length, $r_{0}$ is the pile radius, $r_{\mathrm{m}}$ is the lateral distance from the pile centre at which the shear stress is considered negligible (Randolph and Wroth 1978), $R_{\mathrm{f}}$ is a hyperbolic parameter, and $\tau_{0}$ and $\tau_{\mathrm{f}}$ are the current and limiting shear stress at the pile-soil interface respectively. For the calculation of $\alpha$, this author adopted the elastic solutions documented in Randolph and Wroth (1979):

$$
\alpha_{i j}=\frac{\ln \left(\frac{r_{m}}{s}\right)}{\ln \left(\frac{r_{m}}{r_{0}}\right)}
$$

It is important to note that these values of $\alpha$ were applied to the elastic portion of the soil displacements (which may be obtained by setting the parameter $\beta$ to zero).

As part of the French national project FOREVER, Maleki and Frank (1994) documented the development of the 'GOUPEG' program for the analysis of micropiles installed in groups. This method was considered a hybrid approach. The analysis of a single pile was conducted using the load transfer method. Mindlin's elasticity solutions were used to automatically calculate the 'interactive' displacements induced on adjacent piles. The displacement component of the single pile t-z curves was then modified to account for these additional interactive displacements.

Costanzo and Lancellotta (1998) developed an analytical solution for nonlinear values of $\alpha$ for floating rigid piles. These authors proposed a linear variation of shear modulus with radial distance from the pile to simulate, in a simplified manner, the degradation of shear modulus due to shear strain: 


$$
G(r)=G_{\min }+\frac{G_{\max }-G_{\min }}{r_{l}-r_{0}}\left(r-r_{0}\right)
$$

where $G(r)$ is the current shear modulus at a radius $r$ from the pile, $G_{\max }$ and $G_{\min }$ are the maximum and minimum shear moduli occurring at a very large distance from the pile axis $(r$, taken as $8.0 D)$ and at the interface of the pile $\left(r_{0}\right)$, respectively. The load-transfer relationship was subsequently defined as:

$$
w_{s}=\frac{r_{0}}{G_{\min }} \ln \left(\frac{r_{l}}{r_{0}}\right) \tau_{0}
$$

The free-field displacement field around a loaded pile (Randolph and Wroth 1979) was used to superimpose the effects of adjacent piles in the group, again ignoring the receiver pile reinforcing effect. The interaction between piles may then be determined as follows:

$$
\alpha=1-\frac{\ln \left(\frac{s}{r_{0}} \frac{G_{\min }}{G(s)}\right)}{\ln \left(\frac{r_{l}}{r_{0}} \frac{G_{\min }}{G_{\max }}\right)}
$$

The influence of a reduced near-pile modulus on $\alpha$ using this approach is presented in Fig. 10. Lee and Xiao (2001) adopted a discontinuous displacement function in order to confine plastic soil behaviour to a thin annulus surrounding a loaded pile (see Fig. 11). Outside of this annulus, the soil was assumed elastic. The pile settlement may be obtained as follows:

$$
w_{s}=\frac{r_{0}}{G_{0}} \ln \left(\frac{r_{m}}{r_{0}}\right) \tau_{0}+\frac{a \tau_{0}}{1-b \tau_{0}}
$$

where $G_{0}$ is the small-strain (initial) stiffness, and parameters $a$ and $b$ describe the nonlinearity of the load-transfer curve (see Fig. 12). The first part of this expression represents the elastic soil displacements and corresponds to the solutions of Randolph and Wroth (1979). The second part represents the nonlinear portion of the displacements, using a hyperbolic model similar to that proposed by Duncan and Chang (1970). Pile interaction is determined using the free-field (elastic) soil displacement according to Randolph and Wroth (1979) and these are applied to the elastic portion of the settlement in equation (22); predictions of the displacement field surrounding a loaded single pile are shown in Fig. 13. Pile interaction is calculated by including the axial rigidity of the receiver pile; the final shear stress mobilisation at the interface is dependent on the relative pile-soil displacement.

Zhang et al. (2010) adopted a hyperbolic load-transfer model for the pile shaft: 


$$
\tau_{0}= \begin{cases}\frac{w_{s}}{c+d w_{s}} ; & w_{s} \leq w_{u} \\ \tau_{f} ; & w_{s} \geq w_{u}\end{cases}
$$

where $c$ and $d$ are the hyperbolic model fitting parameters, and $w_{\mathrm{u}}$ is the displacement required to mobilise $\tau_{\text {f. }}$. Although parameters $c$ and $d$ should ideally be calibrated against measured experimental or field data, they may also be estimated from the following expressions (Zhang et al. 2010):

$$
\begin{gathered}
c=\frac{r_{0} \ln \left(\frac{r_{m}}{r_{0}}\right)}{G} \\
d=\frac{R_{f}}{\tau_{f}}
\end{gathered}
$$

where $\mathrm{G}$ is the shear modulus of the soil around the pile shaft. By contrast, no such guidance is provided for $w_{\mathrm{u}}$ in the absence of measured field or laboratory data. Pile interactive displacements were obtained by superimposing elastic free-field soil displacements according to Randolph and Wroth (1979) as defined in equation (18).

Zhang and Zhang (2011) considered interaction between piles with dissimilar lengths. The elastic solutions of Randolph and Wroth (1979) were adopted to describe the load-transfer relationship; nonlinearity of the load-displacement behavior of a single pile was included by imposing a maximum shear stress at the pile-soil interface. Instead of using the free-field displacement for the determination of the response of the non-loaded receiver pile, these authors also included the effect of the axial rigidity of the pile:

$$
E_{p} A_{p} \frac{d^{2} w_{j}(z)}{d z^{2}}-k_{z} \Delta w_{j}=0
$$

where $z$ is the depth below ground level, $w_{\mathrm{j}}$ is the pile displacement at point $\mathrm{j}, k_{\mathrm{z}}$ is the soil Winkler spring stiffness, $\Delta w_{\mathrm{j}}$ is the relative displacement between pile and soil at interface $\mathrm{j}$ of the non-loaded receiver pile, and $E_{\mathrm{p}}$ and $A_{\mathrm{p}}$ are the Young's modulus and area of the pile respectively. Wong and Poulos (2005) adopted approximate relationships to transform interaction factors for piles with identical lengths to those with dissimilar lengths. Modified versions of these expressions were adopted by Zhang and Zhang (2011):

For $L_{\mathrm{i}}>L_{\mathrm{j}}$ :

$$
\alpha_{i j}^{\prime} \approx \frac{\left(\alpha_{i i}+\alpha_{j j}\right)}{f_{1 s}} \frac{1}{R_{1 s}^{K} \cdot R_{1 s}^{L}}
$$


For $L_{\mathrm{i}}<L_{\mathrm{j}}$ :

$$
\alpha_{i j}^{\prime} \approx \frac{\alpha_{j j}}{f_{s 1}} \frac{1}{R_{s 1}^{K} \cdot R_{s 1}^{L}}
$$

where $L_{\mathrm{i}}$ and $L_{\mathrm{j}}$ are the lengths of piles $i$ and $j$ respectively, $f_{1 \mathrm{~s}}$ and $f_{\mathrm{s} 1}$ are the correction factors for $s / D$, pile length difference, and soil modulus distribution, $R_{S 1}^{K}$ and $R_{1 s}^{K}$ are the correction factors for the relative stiffness between the pile and soil, $R_{S 1}^{L}$ and $R_{1 s}^{L}$ are the correction factors for the pile slenderness $(L / D)$. Closed-form expressions for these correction factors are provided in Zhang and Zhang (2011) and Wong and Poulos (2005).

Wang et al. (2012) used a 'BoxLucasl' function to represent both the relationship between the shear stress and local nonlinear displacement at the pile-soil interface, $\Delta S$ :

$$
\tau_{0}=\tau_{f}\left(1-e^{-A \Delta S}\right)
$$

where $A$ is a model parameter defined as follows:

$$
A=\frac{G_{0}}{r_{0} \ln \left(\frac{r_{m}}{r_{0}}\right) \tau_{f}}
$$

The product of $A$ and $\tau_{\mathrm{f}}$ can be considered as the initial stiffness of the curve (see Fig. 14).

Based on the work of Lee and Xiao (2001), the total displacement at the pile-soil interface is obtained by adding the nonlinear displacements described by equation (29) (confined to the pile shaft) and elastic displacements determined using the Randolph and Wroth (1979) equations. These authors proposed an iterative process to account for the degradation in stiffness of a concrete pile under compressive loads using the well-documented nonlinear Hognestad model (Hognestad 1951; Hognestad et al. 1955). The interaction between piles was based on the free-field (elastic) soil displacements which were determined using Randolph and Wroth (1979).

Zhang and Zhang (2012) also adopted the hyperbolic load-transfer model (see equation (23)) employed by Zhang et al. (2010). These authors introduced a 'reduction coefficient', $\lambda$, to account for the reinforcing effect in a simplified manner:

$$
\lambda=\frac{r_{0}}{s} \frac{\ln \left(\frac{r_{m}}{s}\right)}{\ln \left(\frac{r_{m}}{r_{0}}\right)}
$$

The modified interaction factor was therefore defined as: 


$$
\alpha=\left(\frac{s}{r_{0}}-1\right) \lambda
$$

The influence of the reinforcing effect according to this simplified approach is shown in Fig. 15 along with predictions determined using the Mylonakis and Gazetas (1998) approach. For close pile spacings $(s / D<2)$ this model predicts an increase in $\alpha$ when reinforcing effects are taken into account. The minimum value of $s / D$ that should be adopted is therefore equal to 2 . Curiously, the interaction factor defined by equation (32), which is elastic, is applied to the total displacements, i.e. no distinction is made between plastic and elastic displacements.

Jiu and Huang (2014) proposed a simplified approach to consider the nonlinear behaviour of axially-loaded pile groups installed in layered soils. The nonlinearity of soil stiffness was confined to a narrow zone surrounding the soil while the soil medium was considered to be in a linear elastic state based on the findings of Caputo and Viggiani (1984). The nonlinear loaddisplacement behaviour of a single pile was considered using the hyperbolic load-transfer model proposed by Kraft et al. (1981):

$$
w_{s}=\frac{\tau_{0} r_{0}}{G_{0}} \ln \left(\frac{r_{m} / r_{0}-R_{f} \tau_{0} / \tau_{f}}{1-R_{f} \tau_{0} / \tau_{f}}\right)
$$

Solutions for stresses and displacements in a layered elastic half space developed by Ai et al. (2002) were adopted to calculate elastic two-pile interactive displacements, while also accounting for the reinforcing effects of the receiver pile on the soil continuum. The principle of superposition is adopted to extrapolate to group behaviour. It is also possible to simulate realistic flexibility by coupling this analytical approach with FEA, making use of Mindlin's solution for an elastic plate (Mindlin 1951).

Sheil and McCabe (2016a; 2016b; 2017) adopted a nonlinear model for the evolution of soil shear modulus with mean pressure and shear stress level for the development of nonlinear loadtransfer curves previously documented by Lee and Salgado (1999):

$$
G=G_{0}\left(1-f\left(\frac{\tau}{\tau_{f}}\right)^{g}\right)\left(\frac{p^{\prime}}{p_{0}^{\prime}}\right)^{n}
$$

where $G$ is the current shear modulus, $f$ and $g$ are empirical curve fitting parameters, $p^{\prime}$ is the mean effective stress which has a far field value of $p^{\prime}, n$ is a constant between 0.5 and 1 and controls the stress dependency of soil stiffness.

Zhang et al. (2016) also adopted the load-transfer approach proposed by Lee and Xiao (2001) where the total settlement at the pile shaft is decoupled into elastic and plastic displacements. 
Receiver pile reinforcing effects were included by relating the shear stress mobilised on the non-loaded receiver pile to the relative displacement between (i) the displacement field induced by the nearby loaded source pile, and (ii) the displacement of the receiver pile.

\section{Pile base interaction model}

Although the focus of this paper is a review of pile shaft interaction models, a model for the load-displacement relationship at the pile base must be included to enable comparisons with pile groups subjected to compressive axial loads. To this end, the well-documented base model proposed by Chow (1986) has also been adopted here and coupled with the shaft models described above:

$$
w_{b}=\frac{P_{b}\left(1-v_{s}\right)}{2 D G_{b}} \frac{1}{\left(1-\frac{R_{f b} P_{b}}{P_{b u}}\right)^{2}}
$$

where $w_{\mathrm{b}}$ is the pile base settlement; $P_{\mathrm{b}}$ is the pile base load; $v_{\mathrm{s}}$ is the Poisson's ratio of the soil; $G_{\mathrm{b}}$ is the shear modulus at the pile base; $P_{\mathrm{bu}}$ is the limiting base load; and $R_{\mathrm{fb}}$ is a parameter that determines the extent of soil nonlinearity. The interaction between pile bases $\left(\alpha_{b}\right)$ was considered using the Randolph and Wroth (1979) approach:

$$
\alpha_{b}=\frac{2 r_{0}}{\pi r}
$$

\section{COMPARISON OF ANALYTICAL MODELS AGAINST FIELD DATA}

\section{Case I: Single pile and pile group load tests, Belfast, Northern Ireland}

A selection of the aforementioned analytical models have been used to predict the behaviour of a tension-loaded single pile and five-pile group case history at Belfast, Northern Ireland (McCabe 2002; McCabe and Lehane 2006). Precast square concrete piles with an equivalent diameter, $D_{\text {eq }}$, of $0.282 \mathrm{~m}$ were driven to a depth of $6 \mathrm{~m}$ in a soft lightly-overconsolidated estuarine silt deposit. The group piles were arranged in a square quincuncial formation at a spacing-to-diameter $\left(s / D_{\text {eq }}\right)$ ratio of 2.7. An initial elastic shear modulus, $G_{0}$, of $10 \mathrm{MPa}$ was deduced from seismic cone tests which remained relatively constant over the depth of the piles (McCabe 2002). A value of $20 \mathrm{kPa}$ was measured for the in-situ undrained shear strength, $s_{\mathrm{u}}$, (incorporating Bjerrum's correction for plasticity index) using a field shear vane (McCabe and 
Phillips 2008). An adhesion factor of 0.8 combined with a shaft capacity reduction factor, $R_{\mathrm{t}}$, of 0.85 to account for 'barrelling' of the pile and a loss of effective stress due to tension loading (De Nicola and Randolph 1993) results in a value of $\tau_{\mathrm{f}}=13.6 \mathrm{kPa}$.

The parameter selection for each of the analytical approaches is as follows:

i. For the Lee et al. (1993) predictions, $G_{0}$ was adopted for $G_{\mathrm{t}}$ in equation (16) while the value of $r_{\mathrm{m}}$ was calculated as $11.25 \mathrm{~m}$ for undrained conditions (Poisson's ratio, $v=0.5$ ) and a constant-stiffness profile. A value of 0.9 was assumed for $R_{\mathrm{f}}$ in all instances.

ii. For the implementation of their methodology, Costanzo and Lancellotta (1998) adopted a shear strain level of the order of $0.27 \%$; from measured stress-strain curves in triaxial compression (McCabe 2002), this corresponds to values of $G_{\min }$ and $G_{\max }$ of $0.1 G_{0}$ and $G_{0}$ respectively for use in equations (21) and (22). The value of $r_{1}$ was assumed as $8.0 D(2.3$ $\mathrm{m})$.

iii. For the Lee and Xiao (2001) approach, the parameters $a$ and $b$ (equation (22)) were determined as the inverse of the initial shear stiffness at the pile-soil interface (assumed to be equivalent to $G_{0}$ ) and the inverse of $\tau_{\mathrm{f}}$ respectively.

iv. A limiting shear displacement, $w_{\mathrm{u}}$, of $5 \mathrm{~mm}$ was adopted in equation (23) for the Zhang et al. (2010) approach based on common values reported in the literature (Sheil and McCabe 2016a). Parameters $c$ and $d$ were determined using equations (24) and (25) respectively.

v. In the Wang et al. (2012) method, parameter A was determined using equation (30).

The analytical predictions are compared to measurements of the single pile load-displacement response, interaction between the centre and corner group piles (for $L F=0.5$ ), and group loaddisplacement response in Figs 16(a) - 16(c) respectively.

\section{Case II: Ghent Silos, Belgium}

Goossens and Van Impe (1991) documented a case history of 40 cylindrical reinforced concrete silos founded on a $1.2 \mathrm{~m}$ thick piled raft. The foundation had a footprint of $34 \mathrm{~m}$ by $84 \mathrm{~m}$ and comprised 697 driven cast-in-situ reinforced concrete piles. The piles were $13.4 \mathrm{~m}$ in length (13 $\mathrm{m}$ embedded length), $0.52 \mathrm{~m}$ in diameter and had an enlarged $0.8 \mathrm{~m}$ diameter base. The piles were located in predominantly 'loamy or clayey sand'. Goossens and Van Impe (1991) used cone penetration test data to deduce a maximum shaft resistance, $\tau_{\mathrm{f},-}$ of $\sim 100 \mathrm{kPa}$ and an ultimate base load, $P_{\mathrm{bu}}$, of 2.77 MN. A small-strain shear modulus of $28.6 \mathrm{MPa}$ recommended by Poulos (1993) was also selected here. A default value of 0.9 was adopted for $R_{\mathrm{fb}}$. Two static 
pile load tests that were conducted at the site were documented by those authors as well as thirteen years of settlement monitoring along the length of the silos. The fully loaded silos, which imposed a footprint pressure of $\sim 300 \mathrm{kPa}$, transferred a load of $\sim 1.3 \mathrm{MN}$ to each pile. The normalised spacing between piles $(s / D)$ was calculated as $\sim 3.9$. Given the uniform nature of the loading and the thickness of the raft with respect to its footprint, flexible boundary conditions (i.e. equal pile head loads) were assumed at the pile heads within the foundation. The parameter selection followed the same procedure as the previous case study with the following exceptions:

i. The value of $r_{\mathrm{m}}$ was calculated as $24.4 \mathrm{~m}(v=0.25)$.

ii. In the absence of site-specific data, a default value of $0.25 G_{0}$ was adopted for the Costanzo and Lancellotta (1998) approach. Results using two different values for the parameter $r$ are compared in Fig. 17(b): $r_{1}=8.0 D$ (recommended in Costanzo and Lancellotta 1998) and $r_{1}=r_{\mathrm{m}}=24.4 \mathrm{~m}$.

The analytical predictions are compared to measurements of the single pile tests and the 'shortterm' settlement distribution of the silos (i.e. approximately two years after construction) in Figs $17(a)$ and $17(b)$ respectively.

\section{Case III: Liquid ammonia storage tanks, Thessaloniki, Greece}

Badellas et al. (1988), Georgiadis et al. (1989) and Savvaidis (2003) reported a case history of settlement measurements of a $38 \mathrm{~m}$ diameter liquid storage tank founded on 112 bored piles, 1 $\mathrm{m}$ in diameter and $42 \mathrm{~m}$ long ( $40.7 \mathrm{~m}$ embedded depth). The concrete raft was $0.8 \mathrm{~m}$ thick. The soil profile comprised predominantly silty clay. Undrained shear strengths ranging from $36 \mathrm{kPa}$ to $115 \mathrm{kPa}$ were reported by Georgiadis et al. (1989) while the small strain shear moduli ranged between $33 \mathrm{MPa}$ and $226 \mathrm{MPa}$. The average normalised spacing for the piles was $\sim 3.6$. Flexible boundary conditions were again assumed at the pile heads. Fourteen of the piles were monitored for settlement during a water load test in which the tank was filled with $160 \mathrm{MN}$ of water ( 1.4 MN per pile). The analytical predictions are compared to measurements of the settlement distribution across the diameter of the tanks in Fig. 18. 


\section{Discussion}

From Fig. 16(a), it can be seen that the models documented by Lee and Xiao (2001), Zhang et al. (2010), and to a lesser extent Zhang and Zhang (2012), all provide good predictions of the single pile load-displacement response at the Belfast site. While the Lee (1993) method provides a very good estimate of the initial stiffness, the nonlinearity is significantly underpredicted. The least satisfactory predictions are obtained using the Costanzo and Lancelotta (1998) approach; it should be noted, however, that significantly improved agreement could be obtained if $G_{\min }$ in equations (19) and (20) was a function of strain or stress level (see equation (34) for example) rather than simply selecting a constant value. Surprisingly, none of the approaches provide an accurate prediction of the two-pile interaction factor, $\alpha$, in Fig. 16(c). From Fig. 16(b) the approach documented by Zhang et al. (2010) appears to provide the best agreement to the field data. This may, however, be somewhat fortuitous given that this method over-predicts $\alpha$.

For the Ghent silos case history, all methods appear to provide similar predictions of the loaddisplacement response for the two single pile load tests in Fig. 17(a). This is probably because these methods are dominated by the response of the enlarged pile base and the same base model has been adopted for each approach. It can be seen from Fig. 17(b) that all approaches capture the shape of the settlement distribution reasonably well thereby justifying the assumption of equal pile head loads. In this instance, the methods documented by Lee (1993), Zhang et al. (2010), and Zhang and Zhang (2012) provide the best agreement to the monitored settlements. Two different sets of parameters were used with the approach documented by Costanzo and Lancellotta (1998) i.e. $r_{\mathrm{l}}=8.0 D$ and $r_{\mathrm{l}}=r_{\mathrm{m}}$. The former set of parameters provides relatively poor predictions. However, improved agreement is obtained using the relationship $r_{1}=r_{\mathrm{m}}$.

For the Thessaloniki storage tanks case history, all approaches provide an excellent description of the shape of the settlement distribution again indicating flexible pile cap behaviour. The method by Zhang and Zhang (2012) provides a very good prediction of the settlement distribution followed by the methods of Lee (1993), Wang et al. (2012) and Zhang et al. (2012). It can also be seen that the method proposed by Costanzo and Lancellotta (1998) using $r_{1}=r_{\mathrm{m}}$ provides good agreement.

From an overview of the results presented in Figs 16 - 18, the following general observations can be made regarding each analytical method: 
- Lee (1993): although this method appears to over-predict the stiffness of the loaddisplacement response for a single pile, this is likely to be attributable to the use of $G_{\mathrm{t}}$ $=G_{0}$ in the present paper; the use of a more realistic tangent modulus will therefore provide improved agreement. For working loads where the level of nonlinearity is reduced, this method provides very good predictions of group response.

- Costanzo and Lacellotta (1998): this method provides poor predictions of single pile and pile group response if the relationships proposed in that study are adopted. In particular, one of the difficulties with this approach is the selection of the $G_{\min }$ parameter. For the Ghent silos and Thessaloniki storage tanks case histories, an arbitrary relationship of $G_{\min }=0.25 G_{0}$ was adopted given the lack of detailed site investigation. Refinement of this parameter as well as $r_{1}$ would improve the predictions significantly.

- Lee and Xiao (2001): in general, this method provides a good description of the loaddisplacement response of both a single pile and pile group while the method of determining and applying the pile interactive displacements is rigorous.

- Zhang et al. (2010): while this approach provides a good description of the loaddisplacement response of a single pile, the process of applying elastic interaction factors to the total single pile displacements leads to over-predictions of the settlement of a pile group (albeit slight at working loads).

- Wang et al. (2012): this method captures the initial stiffness of the load-displacement response for a single pile but struggles to capture the highly nonlinear responses considered in the these case histories. Nevertheless, this method provides good predictions of group response due to a rigorous treatment of pile interaction (i.e. application of interaction factors to elastic components of single pile settlement).

- Zhang and Zhang (2012): although this approach exhibits an unusual distribution for the pile interaction factor as a function of pile spacing (see Fig. 16(b)), the application of the interaction factor to the elastic component of the single pile settlement is a more robust procedure compared to its predecessor (Zhang et al. 2010). In light of this, predictions using this method consistently showed good agreement to the measured data.

It should be noted that the predictions presented herein are heavilydependent on the selected input parameters. Insistence upon high quality input parameters that will capture the behaviour 
of a single pile is a key step in capturing pile group response. These parameters should reflect the type of pile, pile installation effects and the soil behaviour.

\section{CONCLUSIONS}

In this paper, a database of simplified models has been collated, for use by foundation specialists, enabling the prediction of the nonlinear pile interaction that occurs within vertically-loaded pile groups. These models were categorised as either empirical or analytical. Recent research on the role of soil stiffness nonlinearity in pile interaction has confirmed that the influence of soil plasticity is confined to a narrow zone of soil surrounding a loaded pile whereas pile interactive displacements remain essentially elastic. This has paved the way for the use of the principle of superposition (i.e. the interaction factor method) within a nonlinear analytical framework. The vast majority (if not all) of existing analytical approaches for predicting nonlinear pile group behaviour are therefore coupled with the interaction factor method.

Three published case histories, involving different pile types, group sizes $(5,112$, and 697 piles) and ground conditions, were considered to appraise predictions determined from a selection of the analytical methods reviewed in the paper. This exercise revealed that non-linear soil behaviour is essential if the highly nonlinear load-displacement response of a small pile group is to be captured accurately. For larger pile groups, the response of the group is dominated by elastic interactions and the contribution of soil-nonlinearity is therefore limited. The merit of including non-linear interaction within a design approach therefore appears to be dependent on the group size under consideration. It is worth noting that when the pile shaft resistance is fully mobilised, the continuous form of the interaction factor methods become less reliable and the use of the above methods at the onset of pile-soil slippage is not recommended. Although the methods explored in this paper provide a more rigorous framework for the analysis of pile group response, accurate assessment of pile / soil input parameters remains one of the key challenges in foundation design.

In contrast to analytical approaches, the majority of empirical approaches are not formed from a theoretical basis. Instead, these methods are developed, calibrated, and validated against a selection of case histories or numerical results. These approaches therefore have an implicit range of applicability that is often over-looked. In particular, approaches developed from 
analyses of smaller pile groups provide overly-conservative predictions of pile interaction for large pile groups. 


\section{NOTATION LIST}

\begin{tabular}{|c|c|}
\hline$\alpha$ & Two-pile interaction factor \\
\hline$\beta$ & Stress-dependent term used in Lee (1993) \\
\hline$\varepsilon$ & Exponent used in Castelli and Maugeri (2002) method \\
\hline$\eta_{\mathrm{f}}$ & Stiffness efficiency of a floating pile group \\
\hline$\eta_{\mathrm{g}}$ & Stiffness efficiency of a pile group \\
\hline$\theta$ & Load dispersion angle \\
\hline$\lambda$ & Pile interaction reduction factor due to receiver pile reinforcing effects \\
\hline$\tau_{\mathrm{f}}$ & Limiting shear stress at pile-soil interface \\
\hline$\tau_{0}$ & Shear stress at pile-soil interface \\
\hline$A$ & Nonlinear fitting parameters used in Wang et al. (2012) method \\
\hline$A_{\mathrm{p}}$ & Area of the pile \\
\hline$a, b$ & Nonlinear fitting parameters used in Lee and Xiao (2001) method \\
\hline$B^{\prime}$ & Pile group width used in Vesic (1969) approach \\
\hline$B_{g}$ & Width of the plan area of a pile group in metres used in Skempton (1953) approach \\
\hline$c, d$ & Nonlinear fitting parameters used in Zhang et al. (2010) method \\
\hline$D$ & Pile diameter (circular) or width (square) \\
\hline$D_{\text {eq }}$ & Equivalent diameter of a non-circular pile \\
\hline$D_{\mathrm{g}}$ & Equivalent diameter of the plan area of a pile group \\
\hline$E_{\mathrm{p}}$ & Young's modulus of the pile \\
\hline$f, g$ & $\begin{array}{l}\text { Nonlinear fitting parameters for soil modulus degradation model (Lee and Salgado } \\
\text { 1999) }\end{array}$ \\
\hline$f_{1 \mathrm{~s}}, f_{\mathrm{s} 1}$ & $\begin{array}{l}\text { Correction factors for pile spacing, pile length difference, and soil modulus } \\
\text { distribution used in Zhang and Zhang (2011) method }\end{array}$ \\
\hline$G_{\max }$ & Maximum (far-field) soil modulus at a distance $r_{1}$ from the pile centre \\
\hline$G_{\min }$ & Minimum shear modulus at the pile-soil interface \\
\hline$G(\mathrm{r})$ & Shear modulus at a distance $r$ from the pile centre \\
\hline$G_{\mathrm{t}}$ & Initial tangent shear modulus at the pile shaft \\
\hline$G_{0}$ & Initial small-strain shear modulus \\
\hline$k_{\mathrm{z}}$ & Soil Winkler spring stiffness \\
\hline$L$ & Pile length \\
\hline$L F$ & Load factor (as a fraction of the capacity of a single pile) \\
\hline
\end{tabular}




\begin{tabular}{|c|c|}
\hline$L_{\mathrm{i}}, L_{\mathrm{j}}$ & Length of pile $i, j$ \\
\hline$N$ & Pile group size \\
\hline$n$ & Constant controlling the stress-dependency of soil stiffness \\
\hline$n_{\mathrm{c}}$ & Number of columns of piles in a pile group \\
\hline$n_{\mathrm{r}}$ & Number of rows of piles in a pile group \\
\hline$\Delta P_{\mathrm{s}}$ & Incremental shaft load \\
\hline$p^{\prime}$ & Current mean effective stress of the soil \\
\hline$p_{0}^{\prime}$ & Far-field (undisturbed) mean effective stress of the soil \\
\hline$q$ & Applied stress \\
\hline$Q_{\mathrm{i}}$ & Load applied to pile $i$ \\
\hline$Q_{\text {lim }}$ & Ultimate limit load as defined in Chin (1970) \\
\hline$R_{\mathrm{f}}$ & Hyperbolic model fitting parameter \\
\hline$R_{s 1}^{L}, R_{1 s}^{L}$ & Correction factors for pile slenderness used in Zhang and Zhang (2011) method \\
\hline$R_{s 1}^{K}, R_{1 s}^{K}$ & $\begin{array}{l}\text { Correction factors for the relative stiffness between the pile and soil used in Zhang } \\
\text { and Zhang (2011) method }\end{array}$ \\
\hline$r_{\mathrm{m}}$ & Lateral distance from the pile wall at which the shear stress is considered negligible \\
\hline$R_{\mathrm{S}}$ & Pile group settlement ratio \\
\hline$R_{\mathrm{s}}^{\prime}$ & Pile group settlement ratio for equal stress \\
\hline$R_{\mathrm{t}}$ & $\begin{array}{l}\text { Shaft capacity reduction factor during tensile loading due to pile barrelling and loss } \\
\text { of effective stress }\end{array}$ \\
\hline$r_{0}$ & Pile radius \\
\hline$s$ & Spacing between piles \\
\hline$S_{\text {ng }}$ & Displacement of a pile group normalised by the pile diameter \\
\hline$S_{\mathrm{ns}}$ & Displacement of a single pile normalised by the pile diameter \\
\hline$S_{\mathrm{sh}}^{\prime}, S_{\mathrm{sh}}$ & $\begin{array}{l}\text { Secant slopes of a hypothetical single pile load-displacement curve used in Kaniraj } \\
\text { (1993) method }\end{array}$ \\
\hline$s_{\mathrm{u}}$ & Undrained shear strength of the soil \\
\hline$S_{\mathrm{u} 0}$ & Far-field (undisturbed) undrained shear strength of the soil \\
\hline$\Delta S$ & Local nonlinear displacement at pile shaft \\
\hline$w_{\text {group }}$ & Displacement of a pile group \\
\hline$\Delta w_{\mathrm{j}}$ & $\begin{array}{l}\text { Relative displacement between pile and soil at interface } \mathrm{j} \text { of the non-loaded receiver } \\
\text { pile }\end{array}$ \\
\hline$\Delta w_{\mathrm{s}}$ & Incremental soil settlement at pile-soil interface \\
\hline
\end{tabular}


$w_{\mathrm{s}}$

$w_{\text {single }}$

$w_{\mathrm{u}}$

$z$

Soil displacement at pile-soil interface

Displacement of a single pile

Displacement required to mobilise limiting shear stress

Depth below ground level 


\section{REFERENCES}

Ai, Z. Y., Yue, Z. Q., Tham, L. G., and Yang, M. (2002). "Extended Sneddon and Muki solutions for multilayered elastic materials." International Journal of Engineering Science, 40(13), 1453-1483.

Bartolomey, A.A., Yushkov, B.S., Doroshkevitch, N.M., Leshin, G.M., Khanin, R.E., Kolesnik, G.S. and Mulyukov, E.I., 1981. Pile foundation settlement. In Proc. Tenth Int. Conf. Soil Mech. Found. Engng., Stockholm, Sweden, Roterdam (pp. 611-614).

Badellas, A., Savvaidis, P. and Tsotos, S., 1988. Settlement measurement of a liquid storage tank founded on 112 long bored piles. In Proceedings of 2nd Inter. Symp. on Field Measurements in Geomechanics (pp. 435-442).

Berezantzev, V. G., Khristoforov, V. S., and Golubkov, V. N. (1961). "Load bearing capacity and deformation of piled foundations " Proc 5th Int. Conf. Soil Mech. Found. Engrg.Paris, France, 11-15.

Brand, E.W., Muktabhant, C., Taechathummarak, A. (1972). "Load tests on small foundations in soft clay". Proceedings on the Performance of Earth and Earth-Supported Structures, ASCE, 1, 903-928.

Broms B. (1979). "Negative skin friction." Proc 6th Asian Regional Conference on Soil Mechanics \& Foundation Engineering. Singapore, 41-75.

Caputo, V., and Viggiani, C. (1984). "Pile foundation analysis: A simple approach to nonlinearity effects." Riv Ital Geotec, 18(1), 32-51.

Castelli, F., and Maugeri, M. (2002). "Simplified nonlinear analysis for settlement prediction of pile groups." Journal of Geotechnical and Geoenvironmental Engineering, ASCE, 128(1), 76-84.

Chin, T. K. (1970). "Estimation of the ultimate load of piles from tests not carried to failure." 2nd South East Asian Conference on Soil Mechanics and Foundation Engineering.

Chow, Y. K. (1986). "Analysis of vertically loaded pile groups." Int. J. Numer. Anal. Methods Geomech., 10, 59-72.

Comodromos, E. M. (2004). "Response evaluation of axially loaded fixed head pile groups using 3D nonlinear analysis." Soil Found, 44(2), 31-39.

Comodromos, E. M., and Bareka, S. V. (2009). "Response evaluation of axially loaded fixedhead pile groups in clayey soils." Int. J. Numer. Anal. Methods Geomech., 33(17), 18391865.

Comodromos, E.M., Papadopoulou, M.C., and Rentzeperis. I.K,. (2009) "Pile foundation analysis and design using experimental data and 3-D numerical analysis", Comput Geotech, 36(5), 819-836.

Comodromos, E. M., Papadopoulou, M. C., and Laloui, L. (2016). "Contribution to the design methodologies of piled raft foundations udner combined loadings." Can Geotech $J$, 53(4), 559-577.

Constanzo, D., and Lancellotta, R. (1998). "A note on pile interaction factors." Soils and Foundations, 38(4), 97-136.

De Nicola, A., and Randolph, M. F. (1993). "Tensile and compressive shaft capacity of piles in sand." Journal of Geotechnical Engineering, 119(23), 1952-1973.

Duncan, J. M., and Chang, C. Y. (1970). "Nonlinear analysis of stress and strain in soils." $J$. Soil Mech. Found. Div., ASCE, 96(5), 1629-1653.

Gens, A., an Nova, R. (1993). "Conceptual bases for a constitutive model for bonded soils and weak rocks." Proceedings of Geotechnical Engineering of Hard Soils-Soft Rocks, Rotterdam, 485-494. 
Georgiadis, M., Pitilakis, K., Tsotsos, S. and Valalas, D. (1989). "Settlement of a liquid storage tank founded on piles." In Proceedings of the 12th International Conference on Soil Mechanics and Foundation Engineering, Rio de Janeiro, Vol. 2, 1057-1060.

Ghalesari, A. T., Barari, A., Amini, P. F., and Ibsen, L. B. (2015). "Development of optimum design from static response of pile-raft interaction." Journal of Marine Science and Technology, 20(2), 331-343.

Goossens, D. and VanImpe, W.F., 1991, May. Long-term settlement of a pile group foundation in sand, overlying a clayey layer. In Proceedings 10th European Conference on Soil Mechanics and Foundation Engineering, Firenze, May(pp. 26-30).

Hognestad, E. (1951). "A study of combined bending and axial load in reinforced concrete members." Bulletin series no. 399. Engineering Experiment Station, University of illinois, Urbana, III.

Hognestad, E., Hanson, N. W., and McHenry, D. (1955). "Concrete stress distribution in ultimate strength design." ACI Journal, 52(4), 455-480.

Jiu, Y., and Huang, M. (2014). "A simplified nonlinear method for pile group analysis considering pile cap flexibility." New Frontiers in Geotechnical Engineering. Proceedings of the Geo-Shanghai 2014 International Conference, A. J. P. ie Han, ShuiLong Shen, Sadik Oztoprak, Jie Huang, ed.Shanghai, China.

$\mathrm{Ju}, \mathrm{J}$. (2015). "Prediction of the settlement for the vertically loaded pile group using 3D finite element analyses." Marine Georesources \& Geotechnology, 33(3), 264-271.

Kaniraj, S. B. (1993). "A semi-empirical equation for settlement ratio of pile foundations." Soil Found, 33(2), 82-90.

Kausel, E., and Roësset, J. M. (1981). "Stiffness matrices for layered soils." Bulletin of the Seismological Society of America, 71(6), 1743-1761.

Kempfert, H. and Rudolf, M., 2005. Effects of actions due to group effect on the superstructure on pile groups. In Proceedings of the International Conference on Soil Mechanics and Geotechnical Engineering (Vol. 16, No. 4, p. 2133). AA Balkema Publishers.

Koizumi, Y. and Ito, K., 1967. Field tests with regard to pile driving and bearing capacity of piled foundations. Soils and Foundations, 7(3), pp.30-53.

Kraft, L. M., Ray, R. P., and Kagawa, T. (1981). "Theoretical t-z curves." Journal of the Geotechnical Engineering Division, ASCE, 107(11), 1543-1561.

Kumar, A., Patil, M., and Choudhury, D. (2017). "Soil-structure interaction in a combined pileraft foundation - a case study." Proc ICE - Geotech Eng, 170(2), 117-128.

Lee, C. Y. (1993). "Pile group settlement analysis by hybrid layer approach." ASCE Journal of Geotechnical Engineering, 119(6), 984-997.

Lee, J. H., and Salgado, R. (1999). "Determination of pile base resistance in sands." Journal of Geotechnical and Geoenvironmental Engineering, ASCE, 125(8), 673-683.

Lee, K., and Xiao, Z. (2001). "A simplified nonlinear approach for pile group settlement analysis in multilayered soils." Canadian Geotechnical Journal, 38(5), 1063-1080.

Leung, Y. F., Soga, K., Lehane, B. M., and Klar, A. (2010). "Role of linear elasticity in pile group analysis and load test interpretation." J. Geotech. Geoenviron. Eng., 136(12), 1686-1694.

Liu, J., Xiao, H. B., Tang, J., Li, Q. S. (2004). "Analysis of load-transfer of single pile in layered soils." Comp Geotech. 31:127-35.

Maleki, F. and Frank, R. (1993). "Groupes de pieux chargés axialement. " Project National FOREVER, Programme.

Mandolini, A., and Viggiani, C. (1997). "Settlement of piled foundations." Geotechnique, 47(4), 791-816.

McCabe, B. A. (2002). "Experimental Investigations of Driven Pile Group Behaviour in Belfast Soft Clay." PhD thesis, Trinity College, Dublin. 
McCabe, B. A., and Lehane, B. M. (2006). "Behavior of axially loaded pile groups driven in clayey silt." J. Geotech. Geoenviron. Eng., 132(3), 401-410.

McCabe, B.A. and Phillips, D.T. (2008) "Design lessons from full-scale foundation load tests." Proceedings of the 3rd International Conference on Site Characterization, Taipei, 615620.

McCabe, B. A., and Sheil, B. B. (2015). "Pile group settlement estimation: suitability of nonlinear interaction factors." ASCE Int. J. Geomech., 15(3), 04014056.

Meyerhof, G. G. (1959). "Compaction of sands and beaaring capacity of piles." J. Soil Mech. Found. Engng, ASCE, 85(SM6), 1-30.

Mindlin, R. D. (1951). "Influence of rotatory inertia and shear on flexual motions of isotropic, elastic plates." ASME Journal of Applied Mechanics, 18, 31-38.

Mylonakis, G., and Gazetas, G. (1998). "Settlement and additional internal forces of grouped piles in layered soil." Geotechnique, 48(1), 55-72.

O'Neill, M. W., Hawkins, R. A., Mahar, L. J. (1982). "Load transfer mechanisms in piles and pile groups." Journal of the Geotechnical Engineering Division, ASCE, 108(GT12), $1605-1623$.

Poulos, H. G. (1968). "Analysis of the settlement of pile groups." Geotechnique, 18(4), 449471.

Poulos, H.G., 1993. Settlement prediction for bored pile groups. University of Sydney, School of Civil and Mining Engineering, Centre for Geotechnical Research.

Poulos, H. G. (2006). "Pile group settlement estimation - Research to practice."Shanghai, 122.

Poulos, H. G., and Davis, E. H. (1980). Pile foundation analysis and design, Wiley New York.

Rampello, S. (1994) "Observed behaviour of large diameter bored piles in medium to stiff clay." Proceedings of the Workshop on 'Piled Foundations: Experimental Investigations and, Analysis and Design, Napoli, 407-415.

Randolph, M. F., and Wroth, C. P. (1978). "Analysis of deformation of vertically loaded piles." Journal of the Geotechnical Engineering Division, ASCE, 104(12), 1465-1488.

Randolph, M. F., and Wroth, C. P. (1979). "Analysis of the vertical deformation of pile groups." Geotechnique, 29(4), 423-439.

Savvaidis, P., 2003. Long term geodetic monitoring of the deformation of a liquid storage tank founded on piles. In Proceedings, 11th FIG Symposium on Deformation Measurements, Santorini, Greece.

Sheil, B. B., and McCabe, B. A. (2014). "A finite element based approach for predictions of rigid pile group stiffness efficiency in clays." ACTA Geotechnica, 9, 469-484.

Sheil, B. B., and McCabe, B. A. (2016a). "An analytical approach for the prediction of single pile and pile group behaviour in clay." Comput Geotech, 75, 145-158.

Sheil, B. B., and McCabe, B. A. (2016b). "Reply to discussion by Zhang, Feng, Lie and Zhang on "An analytical approach for the prediction of single pile and pile group behaviour in clay" by Brian B. Sheil and Bryan A. McCabe [Comput. Geotech. 75 (2016) 145-158]." Comput Geotech, 80, 349-350.

Sheil, B. B., and McCabe, B. A. (2017). "Reply to discussion by Li on "An analytical approach for the prediction of single pile and pile group behaviour in clay" by Brian B. Sheil and Bryan A. McCabe [Comput. Geotech. 75 (2016) 145-158]." Comput Geotech, In press.

Sheil, B. B., McCabe, B. A., Hunt, C. E., and Pestana, J. M. (2015). "A practical approach for the consideration of single pile and pile group installation effects in clay: numerical modelling." Journal of Geo-engineering Sciences, 2(3,4), 119-142.

Skempton, A. W. (1953). "Discussion: Piles and pile foundations." Proceedings of the 3rd International Conference for Soil Mechanics and Foundation Engineering. 
Trochanis, A. M., Bielak, J., and Christiano, P. (1991). "Three-dimensional nonlinear study of piles." Journal of Geotechnical Engineering, 117(3), 429-447.

Trofimenkov, J., 1977. Panel contribution, Session 2, Behaviour of foundation and structures. Proc. IX ICSMFE, pp.370-371.

Vesic, A. S. (1969). "Experiments with instrumented pile groups in sand." Performance of Deep Foundations, ASTM, West Conshohocken, Pa., 177-222.

Wang, A. D., Wang, W. D., Huang, M. S., and Wu, J. B. (2016a). "Interaction factor for large pile groups." Géotechnique Letters, 6, 58-65.

Wang, A. D., Wang, W. D., Huang, M. S., Wu, J. B., Sheil, B. B., and McCabe, B. A. (2016b). "Discussion: Interaction factor for large pile groups." Géotechnique Letters, 6, 234240.

Wang, Z., Xie, X., and Wang, J. (2012). "A new nonlinear method for vertical settlement prediction of a single pile and pile groups in layered soils." Computers and Geotechnics, 45(0), 118-126.

Wong, S. C., and Poulos, H. G. (2005). "Approximate pile-to-pile interaction factors between two dissimilar piles." Computers and Geotechnics, 32(8), 613-618.

$\mathrm{Xu}, \mathrm{Y}$., and Zhang, L. M. (2007). "Settlement ratio of pile groups in sandy soils from field load tests." Journal of Geotechnical and Geoenvironmental Engineering, 133(8), 10481054.

Zhang, Q.-Q., Liu, S.-W., Zhang, S.-M., Zhang, J., and Wang, K. (2016). "Simplified nonlinear approaches for response of a single pile and pile groups considering progressive deformation of pile-soil system." Soils and Foundations, 56(3), 473-484.

Zhang, Q.-Q., and Zhang, Z.-M. (2012). "Simplified calculation approach for settlement of single pile and pile groups." Journal of Computing in Civil Engineering, 26(6), 750758.

Zhang, Q.-Q., Zhang, Z.-M., and He, J.-Y. (2010). "A simplified approach for settlement analysis of single pile and pile groups considering interaction between identical piles in multilayered soils." Computers and Geotechnics, 37, 969-976.

Zhang, Q., and Zhang, Z. (2011). "Study on interaction between dissimilar piles in layered soils." International Journal for Numerical and Analytical Methods in Geomechanics, 35(1), 67-81. 
Table 1 Particulars of the field data presented in Fig. 9

\begin{tabular}{lccccc}
\hline Reference & Pile type & Soil conditions & N & L/D & s/D \\
\hline Koizumi \& Ito (1967) & Driven & Silty clay & 9 & 18.5 & 3 \\
& & & & 5 \\
Brand et al. (1972) & Driven & Soft sensitive & 4 & 40 & 4 \\
& & marine clay & & & 2.5 \\
& & & & 2 \\
Trofimenkov (1977) & Driven & Stiff silty clay & 9 & 30 & 3.4 \\
Bartolomey et al. (1981) & Driven & Stiff clay & 9 & 39 & 3 \\
O’Neill et al. (1982) & Driven & Stiff clay & 9 & 48.5 & 3 \\
Rampello (1994) & Bored & Medium - stiff clays & 74 & 47 & 3.1 \\
Randolph \& Clancy (1994) & Bored & Hard silty clay \& & 38 & 25 & 3.5 \\
\hline
\end{tabular}


Table 2 Database of empirical approaches and their range of applicability

\begin{tabular}{|c|c|c|c|c|c|c|c|c|c|}
\hline \multirow[b]{2}{*}{ Reference } & \multirow[b]{2}{*}{ Development } & \multicolumn{8}{|c|}{ Validation data } \\
\hline & & Data & Soil conditions & Installation & Pile type & $\frac{\text { Load level }}{\frac{\text { Single pile capacity }}{}}$ & $\mathrm{N}$ range & $\mathbf{s} / \mathbf{D}$ range & L/D range \\
\hline Skempton (1953) & Field tests & Field tests & Sand & Driven & - & & - & - & - \\
\hline Meyerhof (1959) & Theoretical observations & Field tests & - & - & - & & - & - & - \\
\hline Vesic (1969) & Field tests & Field tests & Medium sand & Jacked & Aluminium pipe & & $4-9$ & $2-6$ & 15 \\
\hline Kaniraj (1993) & $\begin{array}{l}\text { Theoretical observations } \\
\text { from Berezantzev et al. } \\
\text { (1961) modified to fit a } \\
\text { database of field tests }\end{array}$ & Field tests & Sand & & & $\begin{array}{l}0-1 \text { (can account } \\
\text { for nonlinear } \\
\text { behaviour) }\end{array}$ & & & \\
\hline Castelli \& Maugeri (2002) & $\begin{array}{l}\text { Hyperbolic equivalent } \\
\text { pier approach }\end{array}$ & Field tests & Clay, medium sand & Driven & $\begin{array}{l}\text { Steel closed- } \\
\text { ended pipe, } \\
\text { concrete-filled } \\
\text { steel pipe }\end{array}$ & - & $4-140$ & 3 & $33-44$ \\
\hline Comodromos (2004) & 3D elastic-plastic FEA & 3D elastic-plastic FEA & Soft clay & Bored & Concrete & $0-1$ & $4-25$ & 3 & 30 \\
\hline Comodromos \& Bareka (2009) & 3D elastic-plastic FEA & 3D elastic-plastic FEA & Soft clay - stiff clay & Bored & Concrete & $0-1$ & $6-25$ & $2-5$ & $25-50$ \\
\hline McCabe \& Lehane (2006) & $\begin{array}{l}\text { Modified Castelli \& } \\
\text { Maugeri (2002) } \\
\text { hyperbolic approach }\end{array}$ & Field tests & Soft clay - medium sand & Driven & $\begin{array}{l}\text { Concrete, steel } \\
\text { pipe }\end{array}$ & 0.4 & $4-97$ & $2.5-7.1$ & $18.5-26$ \\
\hline Sheil \& McCabe (2015) & 3D nonlinear FEA & Field tests & Clays \& sands & Driven, bored & $\begin{array}{l}\text { Concrete, steel } \\
\text { pipe, timber }\end{array}$ & 0.4 & $4-697$ & $1.8-7.1$ & $14-107$ \\
\hline
\end{tabular}


Table 3 Database of closed-form analytical models for predicting pile interaction and their main features

\begin{tabular}{|c|c|c|c|c|}
\hline Reference & Calibration of shaft load-transfer model parameters & $\begin{array}{l}\text { Soil stiffness } \\
\text { nonlinearity }\end{array}$ & Pile interaction & Pile-soil slip \\
\hline $\begin{array}{l}\text { Caputo \& } \\
\text { Viggiani } \\
\text { (1984) }\end{array}$ & $Q_{\text {lim }}$ determined using Chin (1970) solutions & $\begin{array}{l}\text { Nonlinear } \\
\text { expression for } \alpha_{\mathrm{ii}}\end{array}$ & Use of previously-documented elastic interaction factors. & Not included. \\
\hline Lee (1993) & $\begin{array}{l}R_{\mathrm{f}} \text { may be calibrated against measured load-transfer curves or assumed as } \\
0.9 ; r_{\mathrm{m}} \text { is determined using Randolph \& Wroth (1979) expressions. }\end{array}$ & $\begin{array}{l}\text { Hyperbolic load- } \\
\text { transfer model. }\end{array}$ & $\begin{array}{l}\alpha \text { determined from elastic free-field soil displacements (Randolph \& } \\
\text { Wroth 1979) solutions, applied to the elastic component of the source pile } \\
\text { displacements. }\end{array}$ & $\begin{array}{l}\text { Redistribution of stresses once } \\
\text { pile-soil limiting resistance is } \\
\text { reached }\end{array}$ \\
\hline $\begin{array}{l}\text { Costanzo \& } \\
\text { Lancellotta } \\
(1998)\end{array}$ & $\begin{array}{l}G_{\min } \text { must be determined based on current shear stress level from } \\
\text { measured stress-strain curves; } r_{1} \text { may be determined from FEA or } \\
\text { assumed as eight times the pile diameter. }\end{array}$ & $\begin{array}{l}\text { Lateral variation } \\
\text { in shear modulus. }\end{array}$ & $\begin{array}{l}\alpha \text { determined from elastic free-field soil displacements (Randolph \& } \\
\text { Wroth 1979) solutions, applied to total source pile displacements. }\end{array}$ & Not included. \\
\hline $\begin{array}{l}\text { Lee \& Xiao } \\
(2001)\end{array}$ & $\begin{array}{l}\text { Parameters } a \text { and } b \text { are calibrated against elemental tests of the interface } \\
\text { or measured load-transfer curves. Alternatively } a \text { may be assumed as the } \\
\text { reciprocal of the soil shear stiffness and } b \text { the reciprocal of the limiting } \\
\text { shear stress. Parameter } r_{\mathrm{m}} \text { determined using Randolph \& Wroth (1979) } \\
\text { expressions. }\end{array}$ & $\begin{array}{l}\text { Hyperbolic model } \\
\text { for the nonlinear } \\
\text { portion of the } \\
\text { load-transfer. }\end{array}$ & $\begin{array}{l}\alpha \text { determined from elastic free-field soil displacements (Randolph \& } \\
\text { Wroth 1979) solutions, applied to the elastic component of the source pile } \\
\text { displacements. Influence of receiver pile rigidity considered by imposing } \\
\text { negative skin friction on loaded pile. }\end{array}$ & $\begin{array}{l}\text { Although pile and soil are } \\
\text { considered 'noncompatible', } \\
\text { full pile-soil slip not possible } \\
\text { due to the decoupling of elastic } \\
\text { and plastic displacements. }\end{array}$ \\
\hline $\begin{array}{l}\text { Zhang et al. } \\
(2010)\end{array}$ & $\begin{array}{l}\text { Parameters } c, d, R_{\mathrm{f}} \text { and } w_{\mathrm{u}} \text { are determined experimentally or by back- } \\
\text { analysis of field load tests results; a 'simple' analytical approach is also } \\
\text { available for the estimation of parameters } c \text { and } d \text {. }\end{array}$ & $\begin{array}{l}\text { Hyperbolic load- } \\
\text { transfer model. }\end{array}$ & $\begin{array}{l}\alpha \text { determined from elastic free-field soil displacements (Randolph \& } \\
\text { Wroth } 1979 \text { solutions, applied to total source pile displacements. }\end{array}$ & $\begin{array}{l}\text { Maximum shear stress enforced } \\
\text { at interface introduces pile-soil } \\
\text { slip implicitly. }\end{array}$ \\
\hline $\begin{array}{l}\text { Zhang \& } \\
\text { Zhang (2011) }\end{array}$ & Parameter $r_{\mathrm{m}}$ determined using Randolph \& Wroth (1979) expressions. & $\begin{array}{l}\text { Maximum shear } \\
\text { stress imposed at } \\
\text { interface. }\end{array}$ & $\begin{array}{l}\alpha \text { determined from elastic free-field soil displacements (Randolph \& } \\
\text { Wroth 1979) solutions, applied to total source pile displacements. } \\
\text { Influence of receiver pile rigidity considered by relating relative } \\
\text { settlement to soil spring stiffness. }\end{array}$ & $\begin{array}{l}\text { Maximum shear stress enforced } \\
\text { at interface introduces pile-soil } \\
\text { slip implicitly. }\end{array}$ \\
\hline $\begin{array}{l}\text { Wang et al. } \\
(2012)\end{array}$ & $\begin{array}{l}\text { Parameter } A \text { is calibrated against elemental tests of the interface or } \\
\text { measured load-transfer curves; } r_{\mathrm{m}} \text { determined using Randolph } \& \text { Wroth } \\
(1979) \text { expressions; } R_{\mathrm{f}} \text { may be calibrated against measured load-transfer } \\
\text { curves or assumed as } 0.9 \text {. }\end{array}$ & $\begin{array}{l}\text { BoxLucas1 } \\
\text { function used to } \\
\text { define load- } \\
\text { transfer curve. }\end{array}$ & $\begin{array}{l}\alpha \text { determined from elastic free-field soil displacements (Randolph \& } \\
\text { Wroth 1979) solutions, applied to the elastic component of the source pile } \\
\text { displacements. }\end{array}$ & $\begin{array}{l}\text { Full pile-soil slip not possible } \\
\text { due to the decoupling of elastic } \\
\text { and plastic displacements. }\end{array}$ \\
\hline $\begin{array}{l}\text { Zhang \& } \\
\text { Zhang (2012) }\end{array}$ & See calibration for Zhang et al. (2010). & $\begin{array}{l}\text { Hyperbolic load- } \\
\text { transfer model. }\end{array}$ & $\begin{array}{l}\alpha \text { determined from elastic free-field soil displacements (Randolph \& } \\
\text { Wroth 1979) solutions, applied to the total displacements of the source } \\
\text { pile. Simplified model developed for including pile reinforcing effects. }\end{array}$ & $\begin{array}{l}\text { Maximum shear stress enforced } \\
\text { at interface introduces pile-soil } \\
\text { slip implicitly. }\end{array}$ \\
\hline $\begin{array}{l}\text { Jiu \& Huang } \\
\text { (2014) }\end{array}$ & $\begin{array}{l}\text { Parameter } r_{\mathrm{m}} \text { determined using Randolph \& Wroth (1979) expressions; } R_{\mathrm{f}} \\
\text { may be calibrated against measured load-transfer curves or assumed as } \\
0.9 \text {. }\end{array}$ & $\begin{array}{l}\text { Hyperbolic load- } \\
\text { transfer model. }\end{array}$ & $\begin{array}{l}\text { Interactive displacements determined using elastic solutions documented } \\
\text { by Ai et al. (2002) which also consider receiver pile reinforcing effects. }\end{array}$ & Not included. \\
\hline $\begin{array}{l}\text { Zhang et al. } \\
\text { (2016) }\end{array}$ & See calibration for Lee and Xiao (2001) & $\begin{array}{l}\text { Hyperbolic model } \\
\text { for the nonlinear } \\
\text { portion of the } \\
\text { load-transfer. }\end{array}$ & $\begin{array}{l}\alpha \text { determined from elastic free-field soil displacements (Randolph \& } \\
\text { Wroth 1979) solutions, applied to the elastic component of the source pile } \\
\text { displacements. Influence of receiver pile rigidity considered by imposing } \\
\text { negative skin friction on loaded pile. }\end{array}$ & $\begin{array}{l}\text { Full pile-soil slip not possible } \\
\text { due to the decoupling of elastic } \\
\text { and plastic displacements. }\end{array}$ \\
\hline
\end{tabular}


(a)

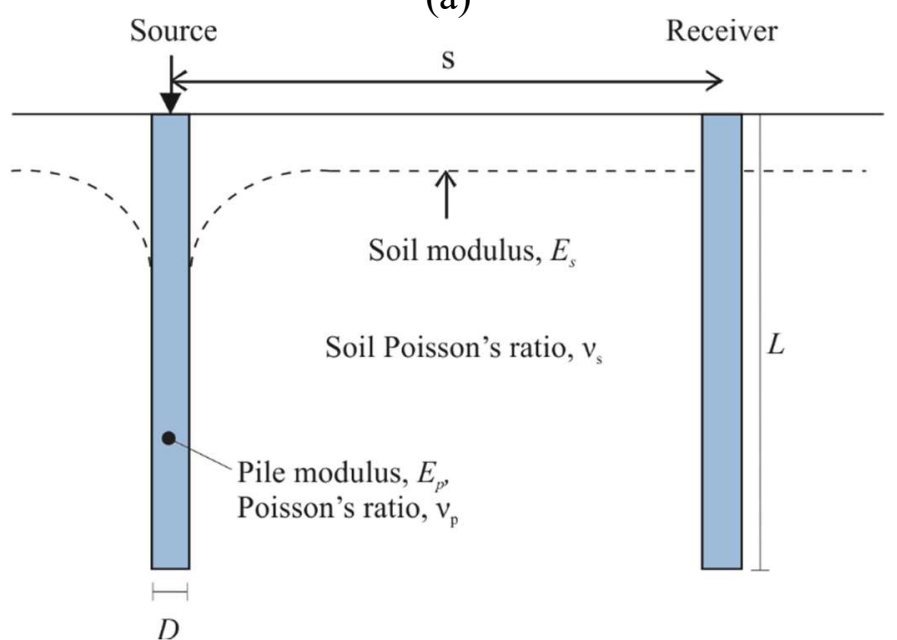

(b)

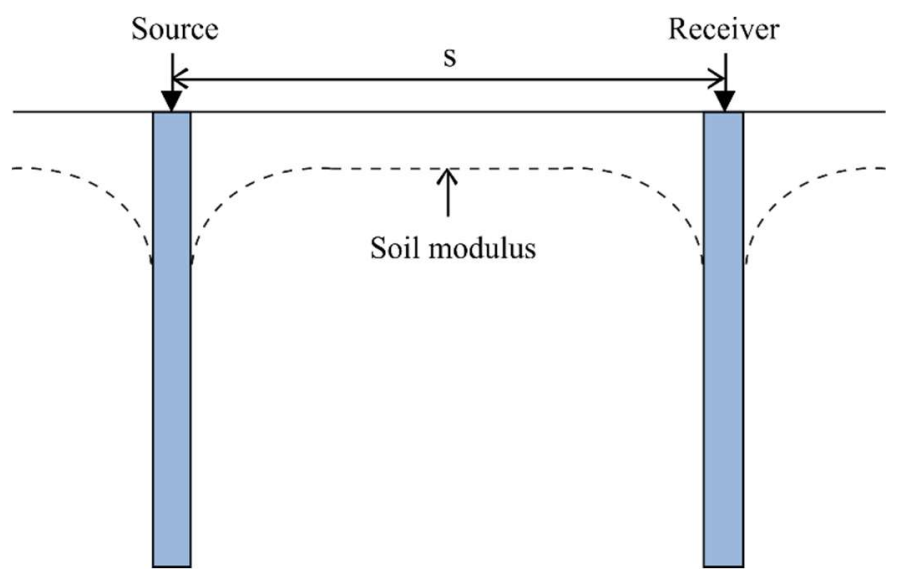

Fig. 1 Illustration of (a) Approach I and (b) Approach II interaction factors 


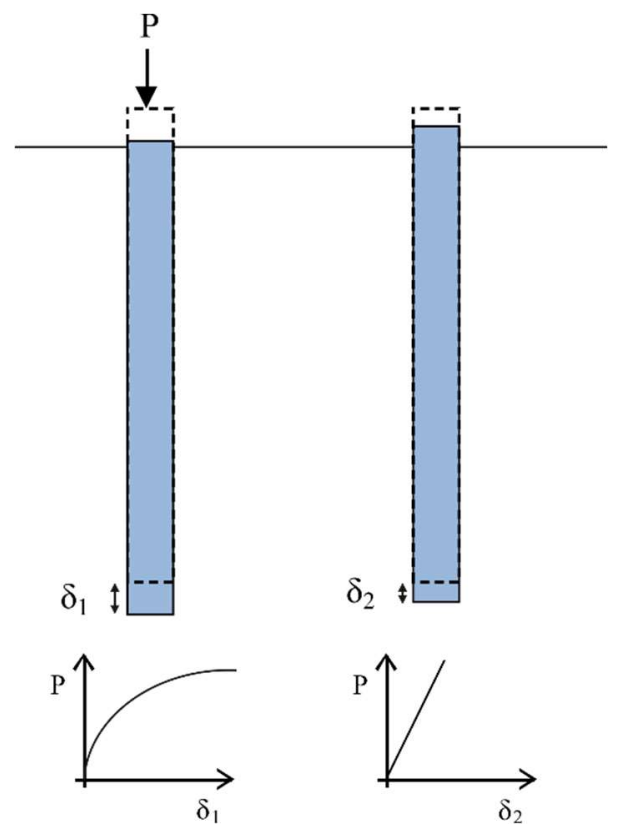

Fig. 2 Illustration of case history and findings documented by Caputo and Viggiani (1984) 


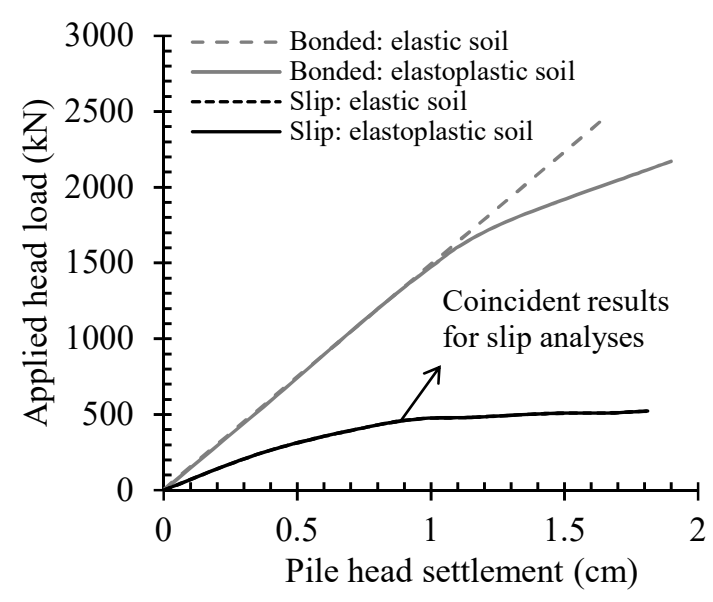

Fig. 3 Influence of slip on the response of a single vertically loaded pile using FEA coupled with an elastic and elastoplastic (Drucker-Prager) model (after Trochanis et al. 1991); $E_{\mathrm{p}}=20$ $\mathrm{GPa}, v_{\mathrm{p}}=0.3, L=10 \mathrm{~m}, B=0.5 \mathrm{~m}, E_{\mathrm{s}}=20 \mathrm{MPa}, v_{\mathrm{s}}=0.45$. Drucker-Prager parameters: $\phi^{\prime}=$ $16.7^{\circ}, \mathrm{s}_{\mathrm{u}}=34 \mathrm{kPa}$. 


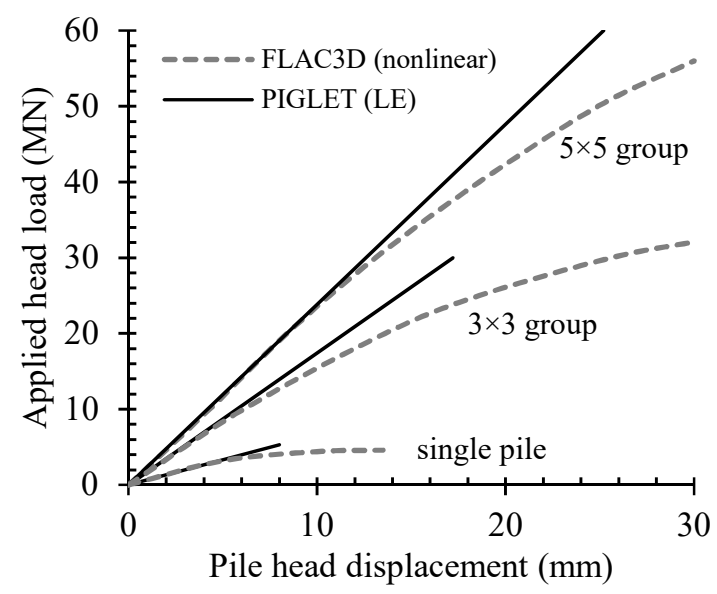

Fig. 4 Comparison of nonlinear and LE numerical analyses (after Leung et al. 2010); no interface elements, pile groups connected to rigid cap , $E_{\mathrm{p}}=30 \mathrm{GPa}, L=20 \mathrm{~m}, D=1 \mathrm{~m}, s=$ $3 \mathrm{~m}, E_{\mathrm{s}}=30 \mathrm{MPa}, s_{\mathrm{u}}=60 \mathrm{kPa}, v_{\mathrm{s}}=0.3$ 


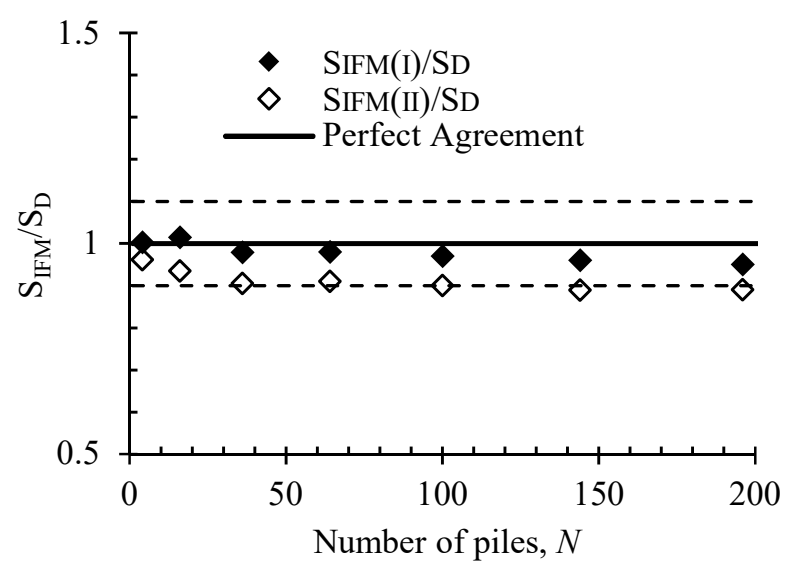

Fig. 5 Comparison between Approach I IFM ( $\left.\mathrm{S}_{\mathrm{IFM}(\mathrm{I})}\right)$, Approach II IFM ( $\left.\mathrm{S}_{\mathrm{IFM}(\mathrm{II})}\right)$, and direct nonlinear $\left(\mathrm{S}_{\mathrm{D}}\right)$ predictions after McCabe and Sheil (2015); Nonlinear, $L / D=25, s / D=3$, rigidly-capped floating pile group 


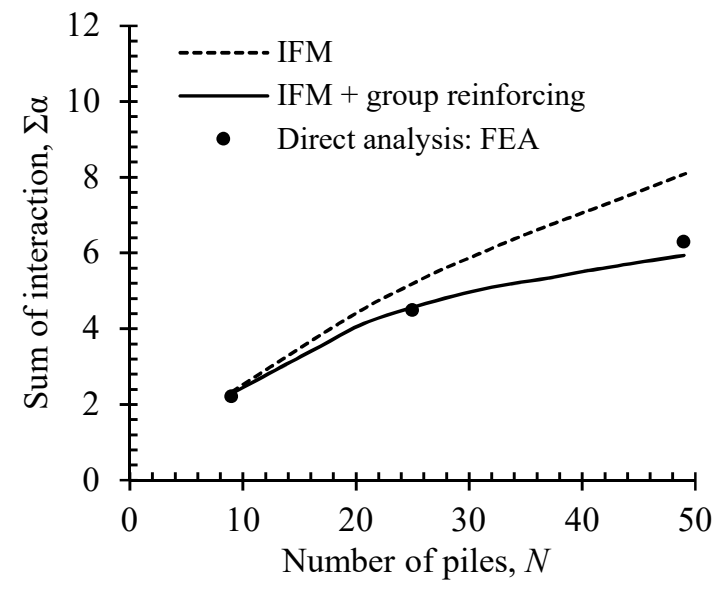

Fig. 6 Comparison of FEA and IFM predictions of the total interaction experienced by a centre group pile; $\mathrm{LE}, L=40 \mathrm{~m}, \mathrm{E}_{\mathrm{s}}=24.5 \mathrm{MPa}, \mathrm{E}_{\mathrm{p}}=19600 \mathrm{MPa}, \mathrm{s}=4 \mathrm{~m}, D=1 \mathrm{~m}, v_{\mathrm{p}}=$ $0.25, v_{\mathrm{s}}=0.45$ 
(a)

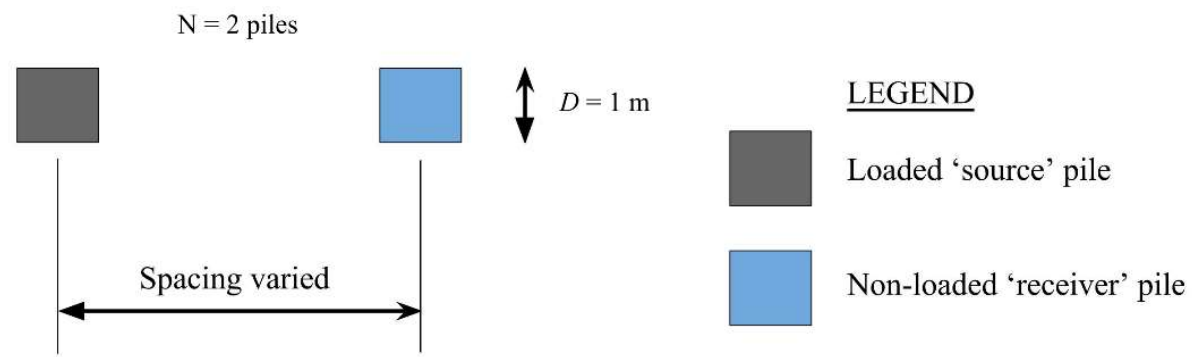

(b)

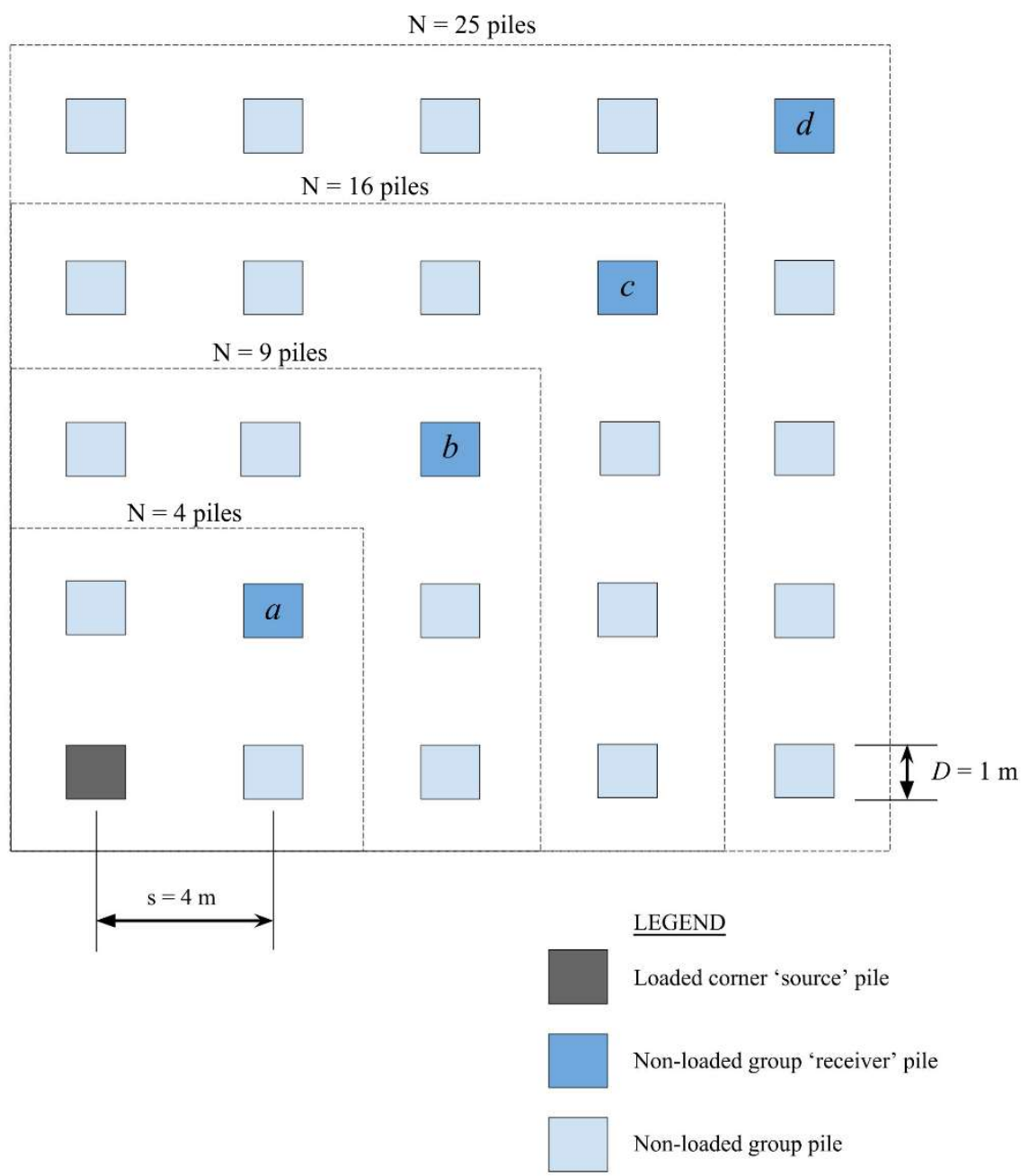

Fig. 7 Illustration of (a) two-pile and (b) pile group geometry (only groups of up to $N=25$ piles shown for clarity) 


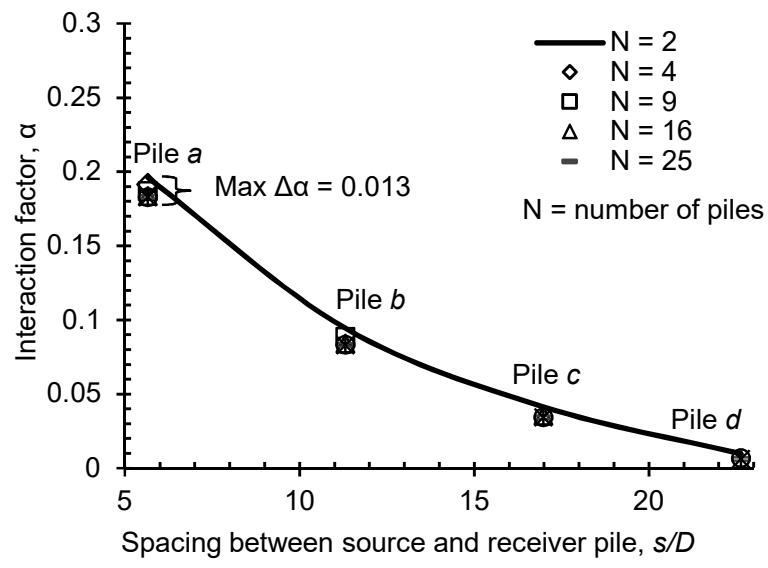

Fig. 8 Influence of intervening free-headed (non-loaded) group piles on two-pile interaction factor using Approach I; $L=40 \mathrm{~m}, E_{\mathrm{s}}=24.5 \mathrm{MPa}, E_{\mathrm{p}}=19600 \mathrm{MPa}, s=4 \mathrm{~m}, D=1 \mathrm{~m}, v_{\mathrm{p}}=$ $0.25, v_{\mathrm{s}}=0.45$ 
(a)

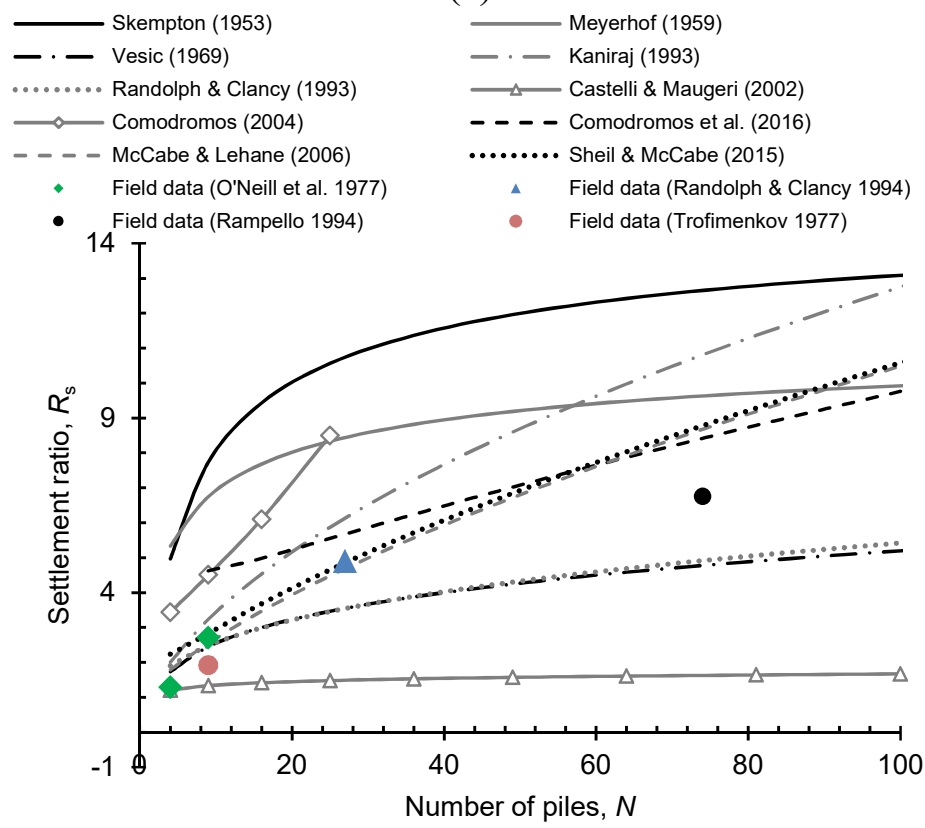

(b)

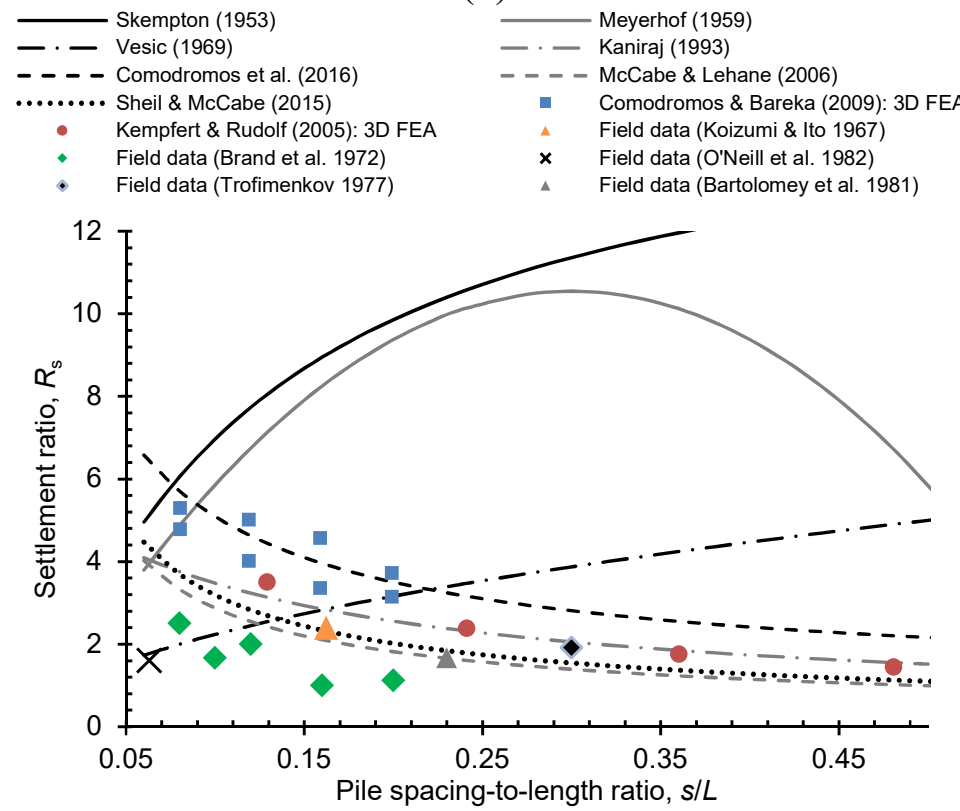

Fig. 9 Comparison of settlement ratio predictions determined using existing empirical approaches: influence of (a) number of piles with common spacing $s=3.0 D(L / D=25)$, (b) pile spacing-to-length ratio for a $3 \times 3$ group layout $(L / D=25)$ 


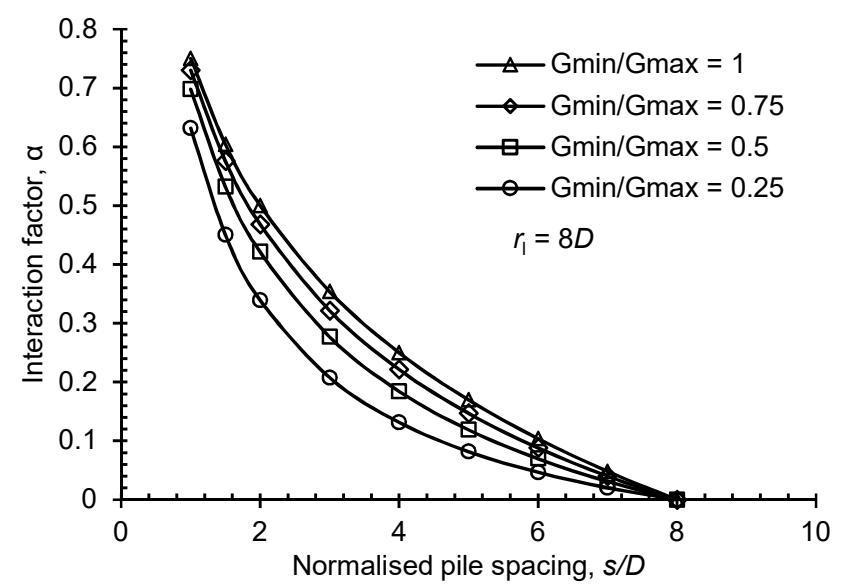

Fig. 10 Influence of reduced 'near-pile' modulus on $\alpha$ (after Costanzo and Lancellotta 1998) 


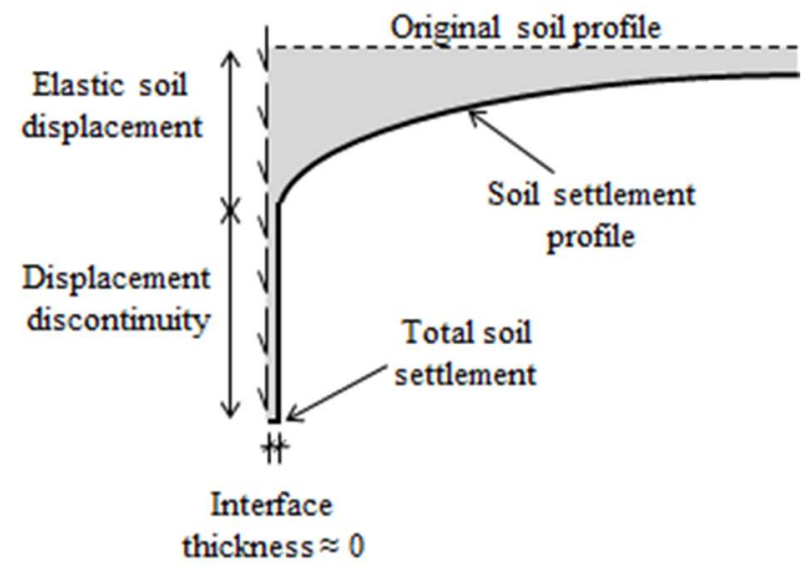

Fig. 11 Illustration of displacement discontinuity concept adopted by Lee and Xiao (2001) 


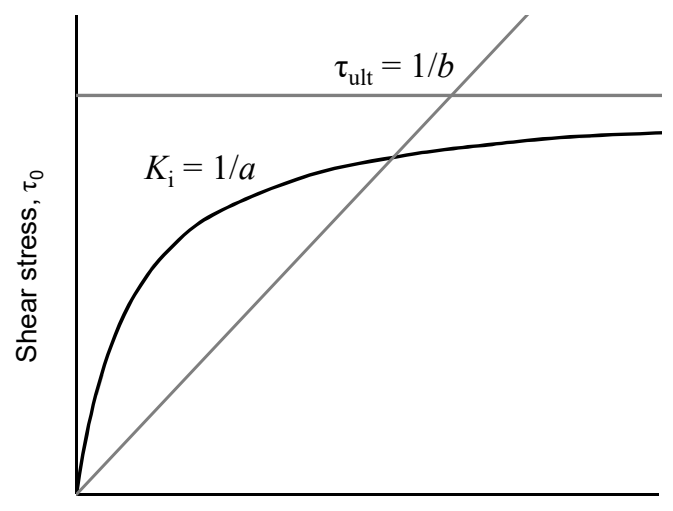

Pile-soil relative displacement, $\Delta S$

Fig. 12 Hyperbolic relationship between shear stress and relative displacement at pile-soil interface adopted by Lee and Xiao (2001) 
(a)

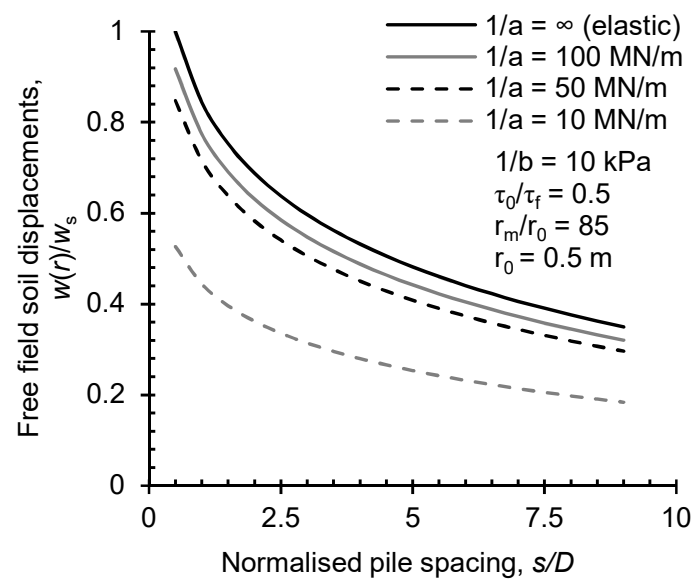

(b)

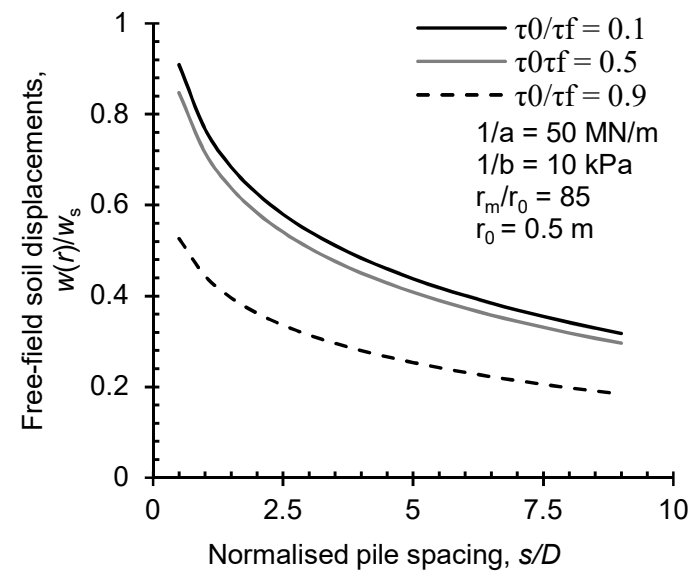

Fig. 13 Normalised free-field soil displacements surrounding a loaded single pile (after Lee and Xiao 2001): (a) influence of parameter $a$, (b) influence of load level 


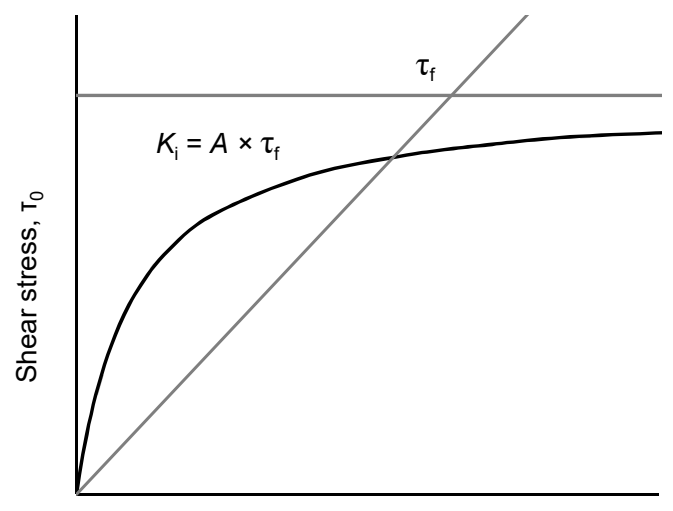

Pile-soil relative displacement, $\Delta S$

Fig. 14 BoxLucas1 relationship between shear stress and relative displacement at pile-soil interface adopted by Wang et al. (2012) 


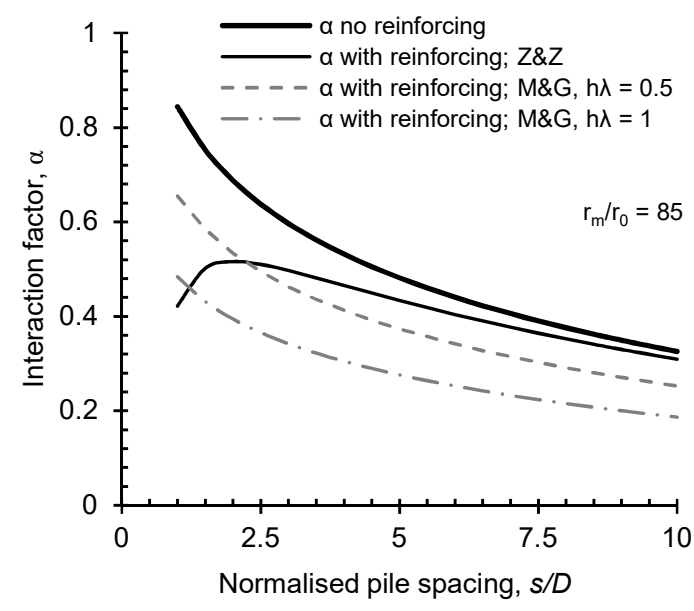

Fig. 15 Comparison of Zhang and Zhang (2012; 'Z\&Z') simplified model for receiver pile reinforcing effects to that proposed by Mylonakis and Gazetas (1998, 'M\&G') 
(a)

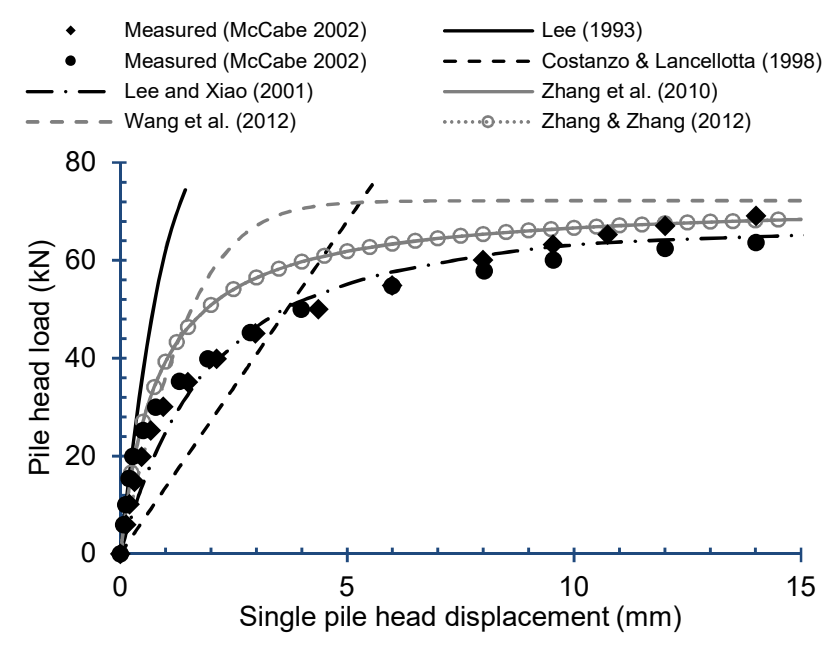

(b)

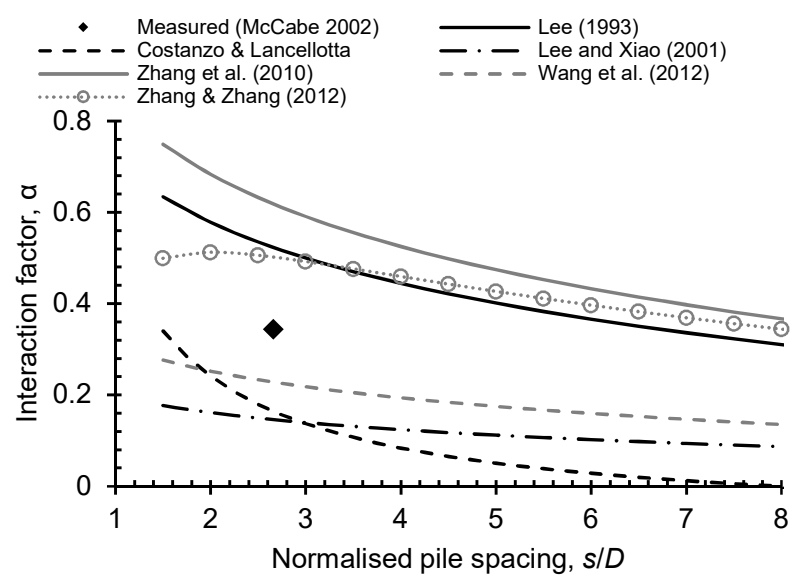

(c)

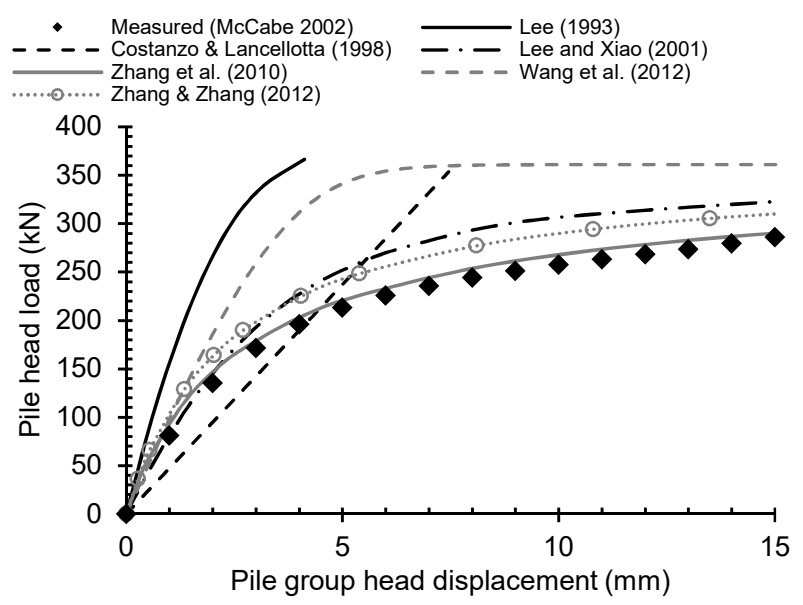

Fig. 16 Comparison of selected analytical approaches to Belfast case history: (a) single pile load-displacement response, (b) two-pile interaction factors (load factor $=0.5$ ), (c) five-pile group load-displacement response; tension loading 
(a)

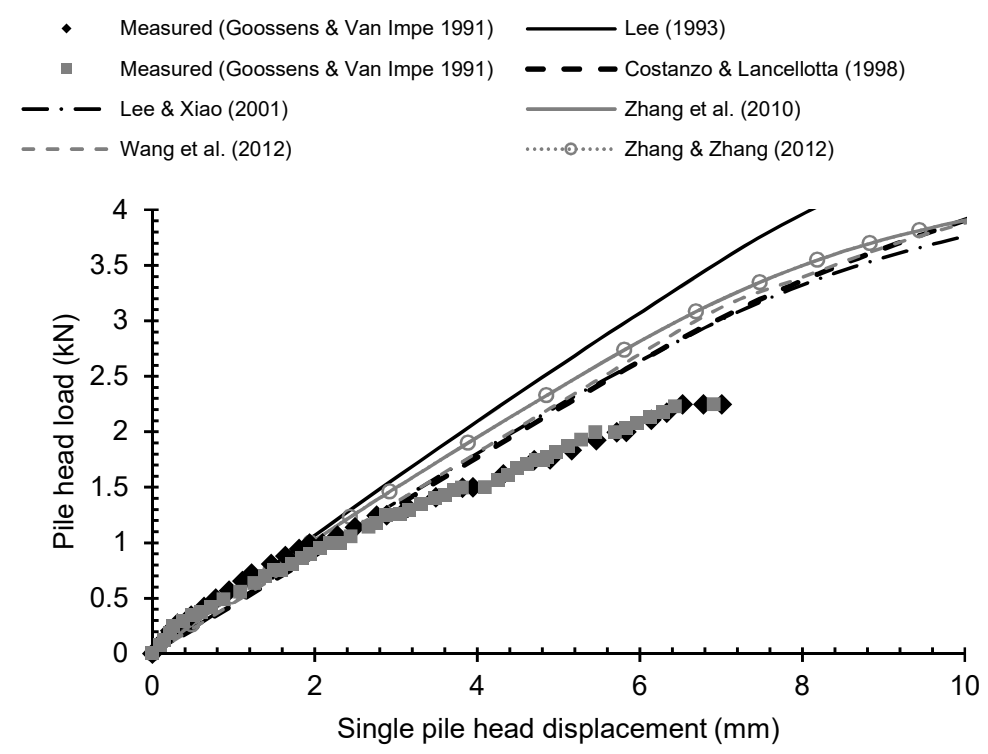

(b)

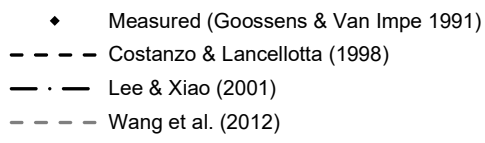
- Lee (1993)
- - - - Costanzo \& Lancellotta (1998); rl=rm
Zhang et al. (2010)
.......... Zhang \& Zhang (2012)

Settlement measurement benchmarks

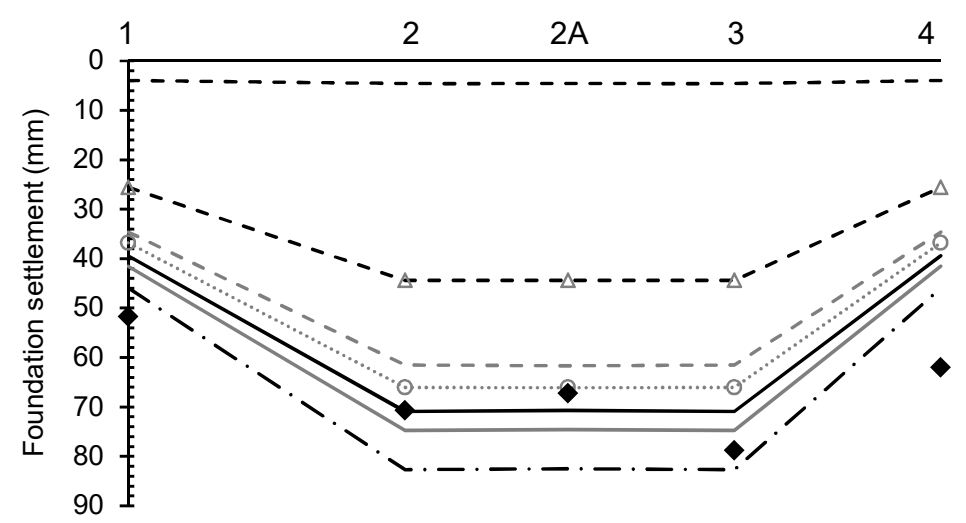

Fig. 17 Comparison of selected analytical approaches to Ghent silos case history: (a) single pile load test, (b) tank settlement distribution across the length of the foundation two years after construction 

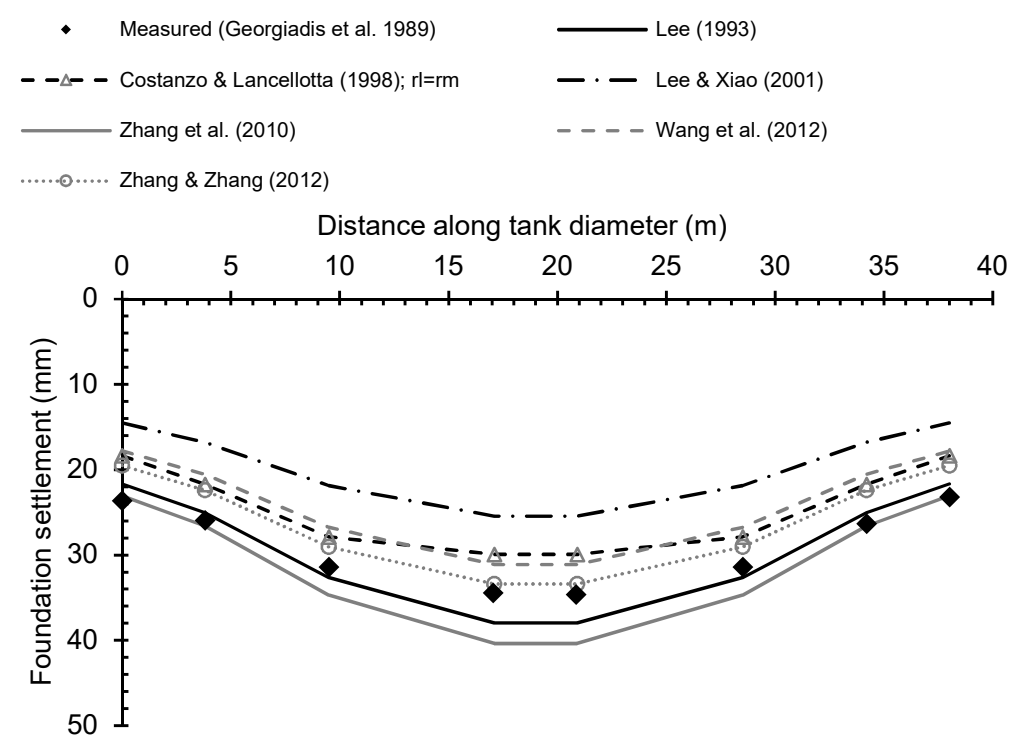

Fig. 18 Comparison of selected analytical approaches to Thessaloniki storage tanks case history: settlement distribution across diameter of foundation 